\title{
Economically important species dominate aboveground carbon storage in forests of southwestern Amazonia
}

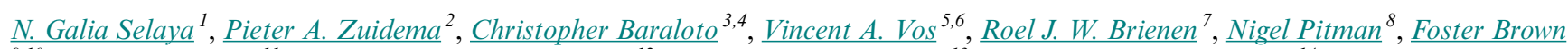 \\ ${ }^{9,10}$, Amv E. Duchelle $^{11}$, Alejandro Araujo-Murakami ${ }^{12}$, Luis A. Oliveira Carillo $^{13}$, Guido H. Vasquez Colomo $^{14}$, Severo Meo \\ Chupinagua ${ }^{15}$, Hugo Fuentes Nay ${ }^{16}$ and Stephen Perz ${ }^{1}$
}

\begin{abstract}
Tree species in tropical forests provide economically important goods and ecosystem services. In submontane forests of southwestern Amazonia, we investigated the degree to which tree species important for subsistence and trade contribute to aboveground carbon storage (AGC). We used 41 1-hectare plots to determine the species abundance, basal area, and AGC of stems $>10 \mathrm{~cm}$ diameter at breast height (dbh). Economically important taxa were classified using ethnobotanical studies and according to their stem density. These taxa $(n=263)$ accounted for $45 \%$ of total stems, $53 \%$ of total basal area, and $56 \%$ of total AGC, significantly more than taxa with minor or unknown uses (Welch test at $\mathrm{p}<0.05$ ). Taxa with 1-2 stems per hectare, or with fewer than 1 stem per hectare (common and rare) accounted for $35 \%$ of total AGC, more than the $22 \%$ accounted for by dominant taxa. High basal area had a greater impact on AGC than abundance in economic taxa because their populations are skewed to adult trees. Size in these taxa had a median dbh > $40 \mathrm{~cm}$ and few stems in regeneration classes of dbh $<10$ to $20 \mathrm{~cm}$ (e.g., Bertholletia excelsa, Cariniana spp., Cedrelinga spp., Ceiba spp., Dipteryx spp.), whereas dominant Tetragastris spp., and Pseudolmedia spp. had most stems in low diameter classes and a median diameter of $<30 \mathrm{~cm}$. Bertholletia excelsa, with 1.5 stems per hectare, showed the highest basal area of any species and accounted for $9 \%$ of AGC $(11 \mathrm{Mg} / \mathrm{ha})$, twice that of the second-ranking species. Our study shows that economic importance and carbon stocks in trees are closely linked in southwestern Amazonia. Unplanned harvests can disrupt synergistic dual roles altering carbon stocks temporally or permanently. Precautionary measures based on species ecology, demography, and regeneration traits should be at the forefront of REDD+ to reconcile maximum harvesting limits, biodiversity conservation, and sustainable forest management.
\end{abstract}

Key Words: basal area; Bertholletia excelsa; carbon storage; economic importance, REDD+; southwestern Amazonia; taxa abundance

\section{INTRODUCTION}

Tree species in tropical forests are important sources of both goods and ecosystem services. Thus, there may be trade-offs between direct economic gain from forest use and long-term provision of ecosystem services, such as carbon storage, in these forests. For instance, logging and hunting may (temporarily) change carbon stocks in tropical forests (Putz et al. 2012, Osuri et al. 2016). Therefore, understanding how species harvests influence forest carbon stocks is crucial to balance the short-term economic gains from harvesting with the long-term provision of ecosystem services through carbon storage and biodiversity conservation in tropical forests.

The long-term provision of ecosystem services in tropical forests requires avoiding forest conversion to agriculture as well as establishing the sustainable use of the remaining forests. The global approach to realize this centers on the creation of regulatory and financial incentives to reduce carbon losses from land-use change and forest management. The reduction of emissions from deforestation and degradation (REDD+) mechanism has been adopted in the international agreement to curb climate change and was recognized during the UNFCCC
COP21 meeting in Paris in December 2015 (United Nations 2015). In recent years, several tropical countries have developed several projects within the REDD+ framework (Sills et al. 2014). The principle of REDD+ is to put a price on carbon retained in forest lands in developing countries in which unplanned deforestation is imminent; therefore the quantification of current forest carbon stocks and potential loss is critical.

We focused on southwestern Amazonia. This is a region that harbors many tree and palm species with high economic and ecological importance, but that has also experienced extensive human immigration, road building, and intensive logging. These developments may put the natural wealth and provision of ecosystem services at risk (Pfaff et al. 2007, Southworth et al. 2011, Perz et al. 2013). Over the last decade, anthropogenic loss of forest in the region has been exacerbated by severe droughts that have caused extensive fires and concomitant $\mathrm{CO}_{2}$ emissions (Foley et al. 2007, Marengo et al. 2008, Aragão and Shimabukuro 2010, Lewis et al. 2010). In southwestern Amazonian forests, aboveground biomass stocks have been estimated to range between 100 and $300 \mathrm{Mg} \mathrm{ha}^{-1}$ (Asner 2009, Salimon et al. 2011, Saatchi et al. 2011), of which living trees can represent around

\footnotetext{
${ }^{1}$ University of Florida, Florida, USA, ${ }^{2}$ Forest Ecology and Forest Management, Wageningen University, The Netherlands, ${ }^{3}$ International Center for Tropical Botany, Florida International University, Florida, USA, ${ }^{4}$ INRA, UMR Ecologie des Forets de Guyane, French Guiana, ${ }^{5}$ Universidad Autónoma del Beni, Bolivia, ${ }^{6}$ Centro de Investigación y Promoción del Campesinado, Regional Norte Amazónico, Riberalta, Bolivia, ${ }^{7}$ School of Geography, University of Leeds, UK, ${ }^{8}$ Science and Education, The Field Museum, Chicago, Illinois, USA, ${ }^{9}$ Woods Hole Research Center, Massachusetts, USA, ${ }^{10}$ Federal University of Acre, Brazil, ${ }^{11}$ Center for International Forestry Research (CIFOR), Bogor, Indonesia, ${ }^{12}$ Museo de Historia Natural Noel Kempff Mercado, Universidad Autónoma Gabriel René Moreno, Santa Cruz, Bolivia, ${ }^{13}$ Unidad Academica Las Piedras, Universidad Amazónica de Pando, Bolivia, ${ }^{14}$ Universidad Amazónica de Pando, Bolivia, ${ }^{15}$ Biology Department, ACBN, Universidad Amazónica de Pando, ${ }^{16}$ Herencia, Bolivia
} 
$82 \%$ of the total (Cummings 2002). These estimates have been derived from forest inventories, allometric equations, and remotesensing techniques. However, the relative contributions of individual species to the total carbon stocks have only recently begun to receive attention. Fauset et al. (2015) provided the first estimates of species contributions in the entire Amazon, and at the regional level, and showed the important economic species Bertholletia excelsa, the Brazil nut tree, ranking third in aboveground woody biomass and accounting for $1.3 \%$ of total biomass. This is an especially important finding because $B$. excelsa populations are strongly manipulated by humans: positively due to silvicultural management (Kainer et al. 2014) and negatively because of potentially unsustainable seed harvesting (Peres et al. 2003), and in all likelihood because of illegal logging and fire. As a result, $B$. excelsa represents a unique case in which the policy and economics of nontimber forest harvests may strongly affect regional carbon stocks (Guariguata et al. 2017).

We took a closer look at the many tree and palm species that are economically important for regional livelihoods and explored their contribution to forest carbon stocks. This is important for southwestern Amazonian forests because B. excelsa and Hevea brasiliensis have long been a cornerstone to support the local economy and alleviate poverty (Zuidema and Boot 2002, Duchelle et al. 2014a). It is also important because timber extraction in southwestern Amazonia has been intensified, especially in Brazil nut concessions, and therefore conflicts between harvesting nontimber forest products, logging for timber, and carbon storage and biodiversity conservation are arising (Giudice et al. 2012, Rockwell et al. 2015). Information on the dual contribution of species, both direct economic value and environmental services, is crucial for understanding the influence exerted by forest users on species population structures and carbon stocks and for designing sustainable forest management and climate change mitigation efforts.

We used data from 41 permanent plots distributed in 19 sites in the trinational border region of Bolivia, Brazil, and Peru, representative of the submontane, terra firme, and former floodplain old growth forests in which $B$. excelsa is widely distributed. We studied the contribution of taxa to forest structure and carbon storage. Specifically, we asked the following questions:

1. What is the relative contribution of economically important taxa (both nontimber and timber) to the abundance, basal area, and aboveground carbon stocks of old growth submontane forests in southwestern Amazonia?

2. What is the relationship between the density of economically important taxa and forest aboveground carbon stocks?

We expect that our study will serve as a baseline for foresters, policy makers, and conservationists to discuss precautionary measures for forest management and performance-based initiatives and payments for environmental services such as REDD+.

\section{METHODS}

\section{Study sites}

The study was carried out in southwestern Amazonia and included the administrative the regions of Madre de Dios (Peru),
Acre (Brazil), and Pando and northern Beni (Bolivia), comprising an extension of $\sim 31$ million ha (Fig. 1). The region has a warm and seasonal climate, with an average annual temperature of 26-27 ${ }^{\circ} \mathrm{C}$. Mean annual precipitation declines from west to east, from $3000 \mathrm{~mm}$ in Madre de Dios down to $1551 \mathrm{~mm}$ in Riberalta, Bolivia. There is also a north-south precipitation gradient, with 1944 mm in Rio Branco, Acre, Brazil and 1498 in Cobija, and $1551 \mathrm{~mm}$ in Riberalta, Bolivia (Navarro and Ferreira 2009), but overall the region is considered moist because of the precipitation range (1500 to $3500 \mathrm{~mm}$ ) and number of dry months per year (4 months; Chave et al. 2005). Most of the region has an elevation of $\sim 100$ to 600 meters above the sea level (masl) and is considered submontane (IBGE 2012). Montane forests > 600 masl are present in small proportion in southwestern Madre de Dios and northwest of Acre. The predominant physiographic types are alluvial, i.e., ancient mostly not flooded or seasonally flooded floodplains, (43\% Madre de Dios, 6\% Acre, and 19\% Pando) and terra firme forests (48\% Madre de Dios, $80 \%$ Acre, and $78 \%$ Pando; DHV Consultores 1997, Escobedo 2008, Salimon 2011). Around 19.7 million hectares $(65 \%)$ of the total trinational area are classified as potential for timber and nontimber extraction and approximately 8 million hectares, $26 \%$ of the total, are titled for Brazil nut (B. excelsa) extraction (INRA 2008, IUCN 2008, Soliz 2009, Chávez et al. 2012, TEEB 2013). Bertholletia excelsa is distributed in terra firme forest at temperatures of 24.3 to $27.2^{\circ}$ $\mathrm{C}$ and 1400 to $2800 \mathrm{~mm}$ of precipitation (Mori and Prance 1998). In broad terms, physiognomic characteristics have been used to classify these forests as dense or open, i.e., mixtures of trees with either bamboo or palms or both (Encarnación et al. 2008, Navarro and Ferreira 2009, Salimon et al. 2011). The region has lost approximately nine percent of its forest cover to date (Southworth et al. 2011).

Fig. 1. Map of the transboundary region of Madre de Dios, Acre, and Pando in southwestern Amazonia showing sites sampled in 19 submontane (terra firme and floodplain) forests.

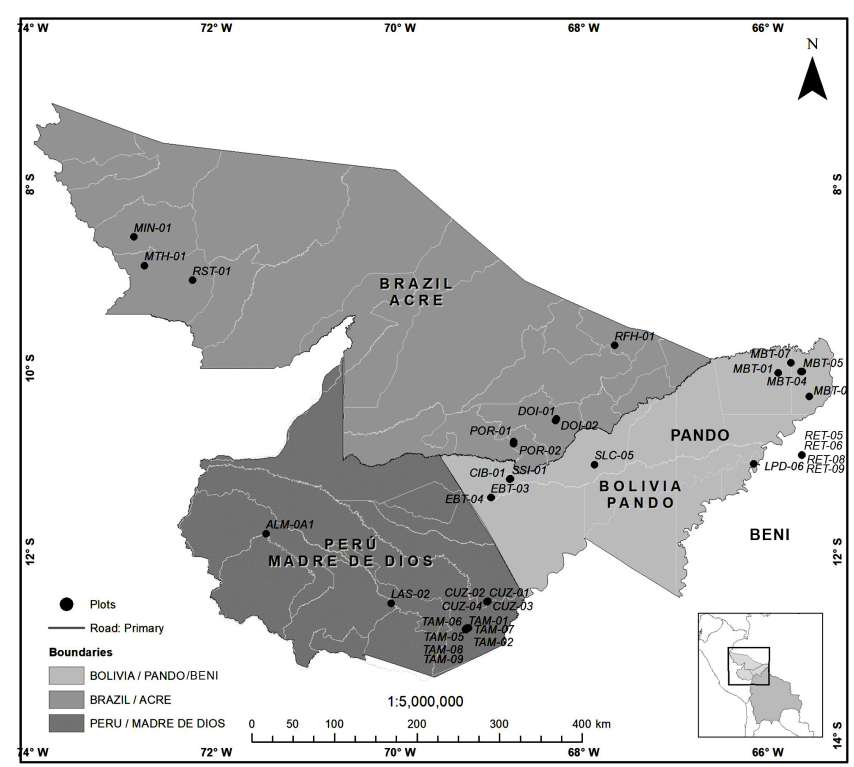




\section{Sampling methods}

We studied 19 sites represented by 41 1-ha permanent plots sampled in the submontane forest, at elevations of 100 to 600 masl. The criteria for selecting sites was to be representative of the main forest types, which at the macro level (thousands of hectares), belong to evergreen seasonal terra firme or to former floodplain mosaics of dense and open bamboo and palm forest types, with bamboo notably in high proportions in the central and western parts, whereas palms were more prevalent in the eastern part of the region (Josse et al. 2007, Mostacedo et al. 2009, Salimon et al. 2011). These sites include forests, typical and representative for the region, which are managed for nontimber and timber products. Bertholletia excelsa is widely distributed across these transboundary terra firme forest types, with the exception of the extreme northwest of Acre and the west of Madre de Dios. We did not follow stratified or random sampling because of costs and site access restrictions. Our selection of sites depended also on obtaining permission from local stakeholders. Of the plots, 30 out of 41 were located in terra firme sensu stricto and 11 were in former floodplains of alluvial origin (https://www. forestplots.net/). A description of the sampled sites is in Appendix 1.

Plots were established following RAINFOR protocol (Phillips et al. 2009). In each plot, all individual trees, palms, and lianas with a diameter at breast height of $1.30 \mathrm{~m}(\mathrm{dbh})>10 \mathrm{~cm}$ were counted, and their diameters at breast height were recorded. The basal area $\left(\mathrm{m}^{2}\right)$ of individual trees was calculated as $3.1416 *$ radius $^{2}$ and then summed at the plot level. Specimens were identified to species in the field by expert botanists. Large lianas $(>10 \mathrm{~cm} \mathrm{dbh})$ were not abundant in our plots, but the large herb Phenakospermum guianensis was found in some plots and was included when individuals had a dbh $>10 \mathrm{~cm}$. Bamboo (Guadua spp.) usually does not reach $10 \mathrm{~cm}$ in diameter and was therefore not included in any of the censuses (Londoño and Peterson 1991). For species that could not be identified in the field, morphospecies and voucher specimens were assigned and subsequently identified by comparing them to herbarium collections and the botanical literature at the Noel Kempff Mercado Natural History Museum, Bolivia (Bolivian specimens), the Universidad Nacional San Antonio Abad del Cusco, Peru (Peruvian specimens), and the University of Leeds, UK (Brazilian specimens).

We counted 21,252 stems across the 41 plots. Of these trees, 16,010 (75\%) were identified to 972 species, $4368(21 \%)$ were assigned to 271 genera, $627(3 \%)$ to 43 families, and $247(1 \%)$ were either morphospecies or were coded as unknown taxa. All samples were used to obtain a total number of stems to calculate the proportion of abundance, basal area, and carbon stocks of taxa of interest. We use the terms abundance and density to refer to the number of stems per hectare.

We used published ethnobotanical studies and lists of species with economic importance from the region to assign taxa to timber and nontimber groups (Mostacedo et al. 2003, Dauber et al. 2005, Cossio-Solano 2009, Baraloto et al. 2014, Moraes R. 2014, ITTO 2016). We included all taxa reported to have commercial monetary value or importance for subsistence at local, regional, and global scales. If taxa are used for both timber and nontimber products, they were included only in the category of major use. We further specified other potential uses, i.e., construction (including thatching), firewood, medicine, handcraft and latex, resins, and food for humans and wildlife.

To facilitate the analysis, we grouped nontimber and timber taxa (genera and species) into one of three density classes. Taxa with a density of $>$ two stems per hectare were considered dominant. Taxa with one or two individuals per hectare were considered common, whereas taxa with less than one individual per hectare were considered rare (for a similar classification see Pitman et al. 2001).

\section{Aboveground carbon stock estimation}

Aboveground carbon stocks (AGC) were estimated using aboveground biomass (AGB) of trees and palms with $\mathrm{dbh}>10$ $\mathrm{cm}$. We estimated biomass as a function of $\mathrm{dbh}$ and wood density following the allometric equation of Goodman et al. (2013). We used this equation because it was developed in the region and because we only measured stem diameter. We used the estimated wood density values for Neotropical species compiled by Zanne et al. (2009). We compared aboveground mass estimated with equations published by Chave et al. (2014) and Goodman et al. (2014) and found no significant differences across the 41 sampled plots at $p<0.05$ (F $3.532 p=0.064)$. The Goodman et al. (2014) equation is described below:

$$
\mathrm{AGB}=\exp (-0.9563+(2.4186 * \ln (\mathrm{D}))+(1.5241 * \ln (\mathrm{WD})))
$$

Where:

$\mathrm{AGB}=$ aboveground biomass $(\mathrm{kg}), \mathrm{WD}=\operatorname{wood}$ density $\left(\mathrm{g} \mathrm{cm}^{-3}\right)$, and $\mathrm{D}=$ diameter at breast height $(\mathrm{dbh} ; \mathrm{cm})$.

Aboveground biomass of palms was estimated as compiled by Goodman et al. (2013).

$$
\mathrm{AGB}=\exp (-3.3488+2.7483 * \ln (\mathrm{D}))
$$

We used the factor 0.4735 to convert aboveground biomass into aboveground carbon (Martin and Thomas 2011). Aboveground carbon stored in species was transformed to $\mathrm{CO}_{2-}$ eq (greenhouse gas emitted/reduced in land use and conversion accounting) by multiplying carbon by 3.67 , i.e., the ratio between the molar mass of $\mathrm{CO}_{2}$ and $\mathrm{C}$ (Watson et al. 2000). We used a reference price of US\$5 per $1 \mathrm{Mg}$ of $\mathrm{CO}_{2}$-eq to calculate the potential revenue of carbon stored in taxa based on 2014 market prices (Peters-Stanley and Gonzalez 2014).

\section{Statistical analysis}

We tested for statistically significant differences in relative abundance, basal area, and aboveground carbon between economically important taxa, taxa with minor or unknown uses, and unknown taxa groups across the 411 -ha plots. We also tested for significant differences in relative abundance, basal area, and AGC of economically important taxa grouped as dominant, common, and rare. We applied Welch and post hoc Games-Howell tests instead of ANOVA if normality (Shapiro-Wilk) and homogeneity of variances (Levene) tests on each variable were significant at $\mathrm{p}<0.05$ (McDonald 2014; http://blog.minitab.com/ blog/adventures-in-statistics/did-welchs-anova-make-fishers-classicone-way-anova-obsolete). We performed a simple regression analysis between taxa density (independent) and AGC (dependent variable) and developed a scatter plot between taxa 
density and median diameter to investigate relationships among these variables. We used the statistical software IBM SPSS V23 2016.

\section{RESULTS}

Plot mean stem density, basal area, and aboveground carbon Mean abundance (508 to 545 individuals per plot), basal area (24 to $25 \mathrm{~m}^{2}$ ), and aboveground carbon (128 to $129 \mathrm{Mg}$ ) differed slightly between plots on terra firme and former floodplains (Table 1). However, analysis of variance showed no significant difference at $p<0.05$ between these two edaphic types.

\section{Stem density, basal area, and carbon stocks of tree species in} economic classes

Of the 1298 taxa (species and genera) present in our plots, 263 were exploited for commercial or subsistence purposes. The list of economically important taxa and their densities are presented in Appendix 2. Taxa exploited for nontimber or timber products accounted for $45 \%$ of all stems, $53 \%$ of the total basal area, and $56 \%$ of total AGC. Taxa with minor or unknown uses accounted for $51 \%$ of all stems but accounted for both lower basal area $(43 \%)$ and AGC (40\%). Unknown taxa represented only four percent of total stems (Table 2). Welch tests showed there were significant statistical differences between stems grouped as economically important, minor or unknown use, and unknown taxa when compared for density ( $\left(\right.$ tems ha $\left.{ }^{-1}\right)$, i.e., $F(2,75.68)=288.73, p<$ 0.001 , basal area $\left(\mathrm{m}^{2} \mathrm{ha}^{-1}\right) \mathrm{F}(2,73.05)=212.28$, and aboveground carbon $\left(\mathrm{Mg} \mathrm{ha}^{-1}\right) \mathrm{F}(2,72.89)=203.28, \mathrm{p}<0.001$ (Table 3). GamesHowell post hoc tests showed significant results for all pairwise comparison at $\mathrm{p}<0.05$, except for density between groups of economic importance and minor or unknown use taxa.

We related the proportion of basal area (\%) with stem diameter classes $(\mathrm{cm})$ of taxa grouped in nontimber, timber, and minor or unknown use. The nontimber group showed a bimodal shape with peaks at small diameter classes of $10-20 \mathrm{~cm}$ and at above $100 \mathrm{~cm}$ in diameter. The timber group showed more than a half of basal area skewed to diameter classes above $40 \mathrm{~cm}$ (Fig. 2). Minor or unknown use species had more than half of their basal area in diameter classes below $40 \mathrm{~cm}$.

\section{Relationship between stem density and carbon stock}

The dominant group had $32 \%$ of total stem abundance compared to $13 \%$ for both common and rare economically important taxa. Common and rare taxa had a higher basal area ( $27 \%$ of the total) than that of the dominant group (26\%). Dominant taxa stored $22 \%$ of the total AGC, whereas common and rare together stored $35 \%$ (Table 4). Welch tests showed there were significant differences between dominant, common, and rare groups for abundance $\mathrm{F}(2,69.65)=128.49, \mathrm{p}=0.000$, basal area $\mathrm{F}(2,79.23)$ $=35.93, \mathrm{p}=0.000$, and aboveground carbon $\mathrm{F}(2,78.31)=6.58$, $\mathrm{p}=0.002$ (Table 5). The post hoc Games-Howell for AGC was not significant between stems of dominant and rare taxa $(\mathrm{p}=$ 0.98 ), but significant between common vs. dominant and common vs. $\operatorname{rare}(\mathrm{p}=0.001)$.

We ranked taxa in proportion to their contribution to carbon stocks in our 41 plots. The 62 taxa with the highest carbon stocks are shown in Table 6 . The emblematic nontimber and common B. excelsa had the highest aboveground carbon stock $(11.28 \mathrm{Mg}$ $\left.\mathrm{ha}^{-1}\right)$, representing as much as nine percent of the total. The dominant exploited taxa Tetragastris spp., Pseudolmedia spp., Brosimum spp., Eschweleira spp., Iriartea deltoidea, and Euterpe precatoria also show high values of carbon stocks. Rare commercial important timber taxa, such as Apuleia leiocarpa, Cedrelinga cateniformis, Couratari macrosperma, Dipteryx odorata, Cariniana micrantha, and Ceiba pentandra also rank among the taxa with the highest carbon stocks (Table 6).

Fig. 2. Contribution of diameter classes $(\mathrm{cm})$ to the basal area $(\%)$ in species and genera used for nontimber products (hatched bars), timber products (gray bars). Taxa with minor or unknown use are shown (white bars). Taxa were sampled in 41 1-ha permanent plots located in terra firme and floodplain forests in southwestern Amazonia.

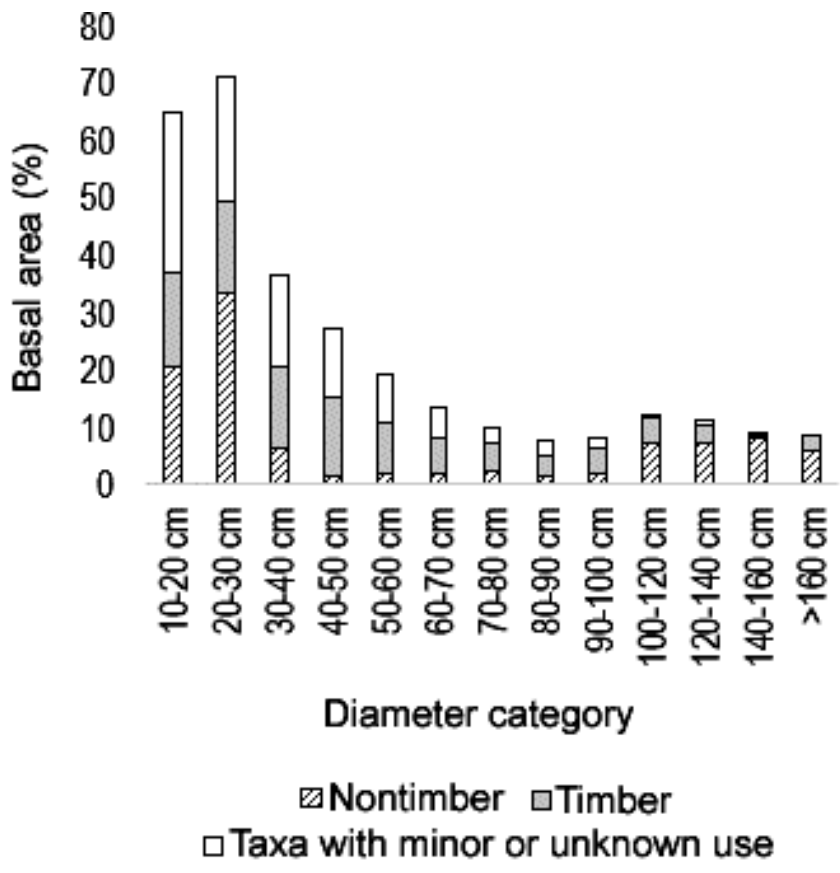

A scatter plot between density (stems per hectare) and median of diameter $(\mathrm{cm})$ for economically important taxa shows nontimber B. excelsa (common) and timber Ceiba spp., Cariniana spp., and Dipteryx spp. (rare) are among the ones skewed to median above $45 \mathrm{~cm}$ at density values below 2 stems per hectare, whereas Tetragastris spp., Pseudolmedia spp., and Euterpe precatoria, among other dominant ones, have a median diameter below 30 $\mathrm{cm}$ (Fig. 3). These taxa showed an inverse-J abundance distribution curve (figure not shown).

The regression analysis between taxa density and aboveground carbon stocks showed a positive relationship $\left(r^{2}=0.43, \mathrm{~F}=289.9\right.$, $\mathrm{p}<0.000$; Fig. 4). There was one prominent outlier in this relation: B. excelsa was the species with the highest AGC stock by far but realized this carbon stock at a relatively low density (1.54 trees per hectare). The explanation for this outlier is the very high median dbh $(100 \mathrm{~cm})$ of $B$. excelsa trees. In this species, $64 \%$ of the stems are $>45 \mathrm{~cm}$ in $\mathrm{dbh}$. The strongly skewed population structure of this species also caused it to be the species with the highest basal area values in this study. 
Table 1. Mean density (number of stems ha $\left.{ }^{-1}\right)$, basal area $\left(\mathrm{m}^{2} \mathrm{ha}^{-1}\right)$, and carbon $\left(\mathrm{Mg} \mathrm{ha}^{-1}\right)$ of 41 plots of 1 ha each $(30$ terra firme and 11 floodplain forests) located in southwestern Amazonia. Standard deviation and analysis of variance results ( $\mathrm{F}$ and significance at $\mathrm{p}$ $<0.05$ ) are shown. Degrees of freedom were 1 in numerator and 39 in denominator.

\begin{tabular}{|c|c|c|c|c|c|c|c|c|c|c|c|c|}
\hline & $\begin{array}{c}\text { Mean } \\
\text { density }\end{array}$ & $\mathrm{SD}$ & $\mathrm{F}$ & sig & $\begin{array}{c}\text { Mean basal } \\
\text { area }\left(\mathrm{m}^{2}\right)\end{array}$ & SD & $\mathrm{F}$ & sig & $\begin{array}{c}\text { Mean AGC } \\
(\mathrm{Mg})\end{array}$ & SD & $\mathrm{F}$ & sig \\
\hline Terra firme & 508 & 86 & 1.523 & 0.2 & 24 & 39 & 0.33 & 0.57 & 128 & 22 & 0.029 & 0.87 \\
\hline $\begin{array}{l}\text { Former } \\
\text { floodplain }\end{array}$ & 545 & 83 & & & 25 & 5 & & & 129 & 12 & & \\
\hline
\end{tabular}

Table 2. Taxa classified according to their major uses as nontimber (food, fibers, latex, medicine, construction, and thatching) and timber (wood for furniture, construction, and firewood). The genus level was used for calculation if use occurs irrespective of species level. Values of minor or unknown use and unknown taxa are shown. Number of taxa, abundance, basal area, and aboveground carbon in absolute values and percentage are shown. Taxa were sampled in 41 1-ha permanent plots located in 19 terra firme and floodplain forests in southwestern Amazonia.

\begin{tabular}{|c|c|c|c|c|c|c|c|}
\hline Taxa use category & $\begin{array}{l}\text { Number } \\
\text { of taxa }\end{array}$ & $\begin{array}{l}\text { Absolute } \\
\text { stems } \\
\text { abundance }\end{array}$ & $\begin{array}{l}(\%) \text { of total } \\
\text { abundance }\end{array}$ & $\begin{array}{l}\text { Absolute } \\
\text { basal area } \\
\left(\mathrm{m}^{2}\right)\end{array}$ & $\begin{array}{l}(\%) \text { of total } \\
\text { basal area }\end{array}$ & $\begin{array}{c}\text { Absolute } \\
\text { aboveground } \\
\text { carbon }(\mathrm{Mg})\end{array}$ & $\begin{array}{l}(\%) \text { of total } \\
\text { aboveground } \\
\text { carbon }\end{array}$ \\
\hline $\begin{array}{l}\text { Species or genera primarily used } \\
\text { for nontimber products }\end{array}$ & 22 & 3331 & 16 & 160 & 16 & 806 & 15 \\
\hline $\begin{array}{l}\text { Species or genera primarily used } \\
\text { for timber products }\end{array}$ & 241 & 6246 & 29 & 370 & 37 & 2162 & 41 \\
\hline $\begin{array}{l}\text { Taxa with minor or unknown } \\
\text { use }\end{array}$ & 980 & 10,801 & 51 & 439 & 43 & 2088 & 40 \\
\hline Unknown taxa and use & 55 & 874 & 4 & 40 & 4 & 212 & 4 \\
\hline Total & 1298 & 21,252 & 100 & 1009 & 100 & 5268 & 100 \\
\hline
\end{tabular}

Table 3. Welch tests statistics (F) for density $\left(\right.$ stems ha $\left.{ }^{-1}\right)$, basal area $\left(\mathrm{m}^{2} \mathrm{ha}^{-1}\right)$, and aboveground carbon $\left(\mathrm{Mg} \mathrm{ha}^{-1}\right)$ of species and genera used for nontimber and timber products, of species and genera with minor and unknown use and unknown taxa. Sampled plots (N), mean, standard deviation, degrees of freedom (df1 and df2), and significance level at $\mathrm{p}<0.005$ are shown. Taxa were sampled in 411 ha permanent plots located in terra firme and floodplain forests in southwestern Amazonia.

\begin{tabular}{|c|c|c|c|c|c|c|c|}
\hline Use & $\mathrm{N}$ & Mean & $\begin{array}{l}\text { Standard } \\
\text { deviation }\end{array}$ & $\begin{array}{c}\text { Welch test } \\
\text { asymptotically } \\
\text { F distributed. }\end{array}$ & df1 & df 2 & $\begin{array}{l}\text { Significance } \\
\text { level }\end{array}$ \\
\hline \multicolumn{8}{|l|}{ Density $\left(\right.$ stems ha $\left.{ }^{-1}\right)$} \\
\hline $\begin{array}{l}\text { Species or genera economically } \\
\text { important }\end{array}$ & 41 & 233.59 & 63.82 & 288.73 & 2.00 & 75.68 & 0.000 \\
\hline $\begin{array}{l}\text { Species or genera with minor } \\
\text { importance or unknown use }\end{array}$ & 41 & 263.44 & 61.83 & & & & \\
\hline Unknown taxa & 39 & 22.41 & 39.86 & & & & \\
\hline Total & 121 & 175.64 & 120.61 & & & & \\
\hline \multicolumn{8}{|l|}{ Basal area $\left(\mathrm{m}^{2} \mathrm{ha}^{-1}\right)$} \\
\hline $\begin{array}{l}\text { Species or genera economically } \\
\text { important }\end{array}$ & 41 & 12.95 & 4.27 & 212.28 & 2.00 & 73.05 & 0.000 \\
\hline $\begin{array}{l}\text { Species or genera with minor } \\
\text { importance or unknown use }\end{array}$ & 41 & 10.70 & 3.17 & & & & \\
\hline Unknown taxa & 39 & 1.02 & 2.00 & & & & \\
\hline Total & 121 & 8.34 & 6.11 & & & & \\
\hline \multicolumn{8}{|l|}{ Aboveground carbon $\left(\mathrm{Mg} \mathrm{ha}^{-1}\right)$} \\
\hline $\begin{array}{l}\text { Species or genera economically } \\
\text { important }\end{array}$ & 41 & 72.38 & 25.50 & 203.27 & 2.00 & 72.89 & 0.000 \\
\hline $\begin{array}{l}\text { Species or genera with minor } \\
\text { importance or unknown use }\end{array}$ & 41 & 50.93 & 14.65 & & & & \\
\hline Unknown taxa & 39 & 5.43 & 10.29 & & & & \\
\hline Total & 121 & 43.53 & 33.12 & & & & \\
\hline
\end{tabular}


Table 4. Economically important nontimber and timber (including construction wood and firewood uses) taxa classified as dominant (taxa with a density of $>$ two stems per hectare), common (taxa with one to two individuals per hectare), or rare (taxa with fewer than one individual per hectare). Number of taxa, abundance (number of stems), basal area $\left(\mathrm{m}^{2}\right)$, and aboveground carbon (Mg) in absolute value and percentage are shown. Values of minor or unknown use and unknown taxa are shown. Taxa were sampled in 41 1-ha plots located in terra firme and floodplain forests in southwestern Amazonia.

\begin{tabular}{|c|c|c|c|c|c|c|c|}
\hline Taxa density category & $\begin{array}{l}\text { Number of } \\
\text { taxa }\end{array}$ & $\begin{array}{l}\text { Number of } \\
\text { stems }\end{array}$ & $\begin{array}{l}\% \text { of total } \\
\text { abundance }\end{array}$ & $\begin{array}{c}\text { Absolute } \\
\text { basal area } \\
\left(\mathrm{m}^{2}\right)\end{array}$ & $\begin{array}{l}\% \text { of total } \\
\text { basal area }\end{array}$ & $\begin{array}{c}\text { Absolute } \\
\text { aboveground } \\
\text { carbon }(\mathrm{Mg})\end{array}$ & $\begin{array}{c}\% \text { of total } \\
\text { aboveground } \\
\text { carbon }\end{array}$ \\
\hline \multicolumn{8}{|l|}{ Dominant } \\
\hline $\begin{array}{l}\text { Species or genera primarily used for } \\
\text { nontimber products }\end{array}$ & 8 & 2991 & 14 & 92 & 9 & 253 & 5 \\
\hline $\begin{array}{l}\text { Species or genera primarily used for } \\
\text { timber products }\end{array}$ & 17 & 3925 & 18 & 169 & 17 & 899 & 17 \\
\hline \multicolumn{8}{|l|}{ Common } \\
\hline $\begin{array}{l}\text { Species or genera primarily used for } \\
\text { nontimber products }\end{array}$ & 2 & 111 & 1 & 49 & 5 & 469 & 9 \\
\hline $\begin{array}{l}\text { Species or genera primarily used for } \\
\text { timber products }\end{array}$ & 12 & 706 & 3 & 40 & 4 & 216 & 4 \\
\hline \multicolumn{8}{|l|}{ Rare } \\
\hline $\begin{array}{l}\text { Species or genera primarily used for } \\
\text { nontimber products }\end{array}$ & 12 & 229 & 1 & 19 & 2 & 84 & 1 \\
\hline $\begin{array}{l}\text { Species or genera primarily used for } \\
\text { timber products }\end{array}$ & 212 & 1615 & 8 & 161 & 16 & 1046 & 20 \\
\hline \multicolumn{8}{|l|}{ Other categories } \\
\hline Taxa with minor or unknown use & 980 & 10,801 & 51 & 439 & 43 & 2088 & 40 \\
\hline Unknown taxa and use & 55 & 874 & 4 & 40 & 4 & 212 & 4 \\
\hline Total & 1298 & 21,252 & 100 & 1009 & 100 & 5268 & 100 \\
\hline
\end{tabular}

Fig. 3. Relationship between median diameter $(\mathrm{cm})$ and density (stems per hectare) of species and genera primarily used for nontimber and timber products. Species and genera with the highest median diameter are labeled. Taxa were sampled in 41 1-ha permanent plots located in terra firme and floodplain forests in southwestern Amazonia.

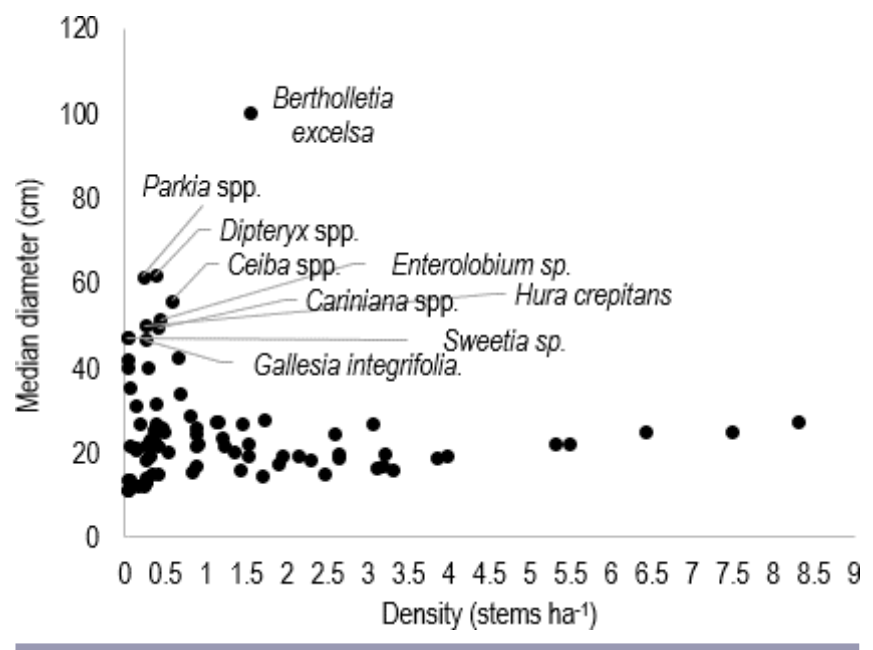

Estimated value of aboveground carbon in $\mathrm{CO}_{2}$-eq units

The average aboveground carbon stock per hectare was 128.48 $\mathrm{Mg}$. This is equivalent to $471.51 \mathrm{Mg} \mathrm{CO}_{2}$-eq ha ${ }^{-1}$. At a referential price of US\$5 per $\mathrm{Mg} \mathrm{CO}_{2}$-eq (Peters-Stanley and Gonzalez 2014), the monetary value of the carbon per hectare in southwestern Amazonia is US\$2357 (Table 7). From the total
Fig. 4. Relationship between density (stems per hectare) and aboveground carbon (AGC; $\mathrm{Mg}$ per hectare) of species and genera sampled in 41 1-ha permanent plots located in terra firme and floodplain forests in southwestern Amazonia. Species and genera with the highest AGC values are labeled. $\mathrm{R}^{2}=0.43$.

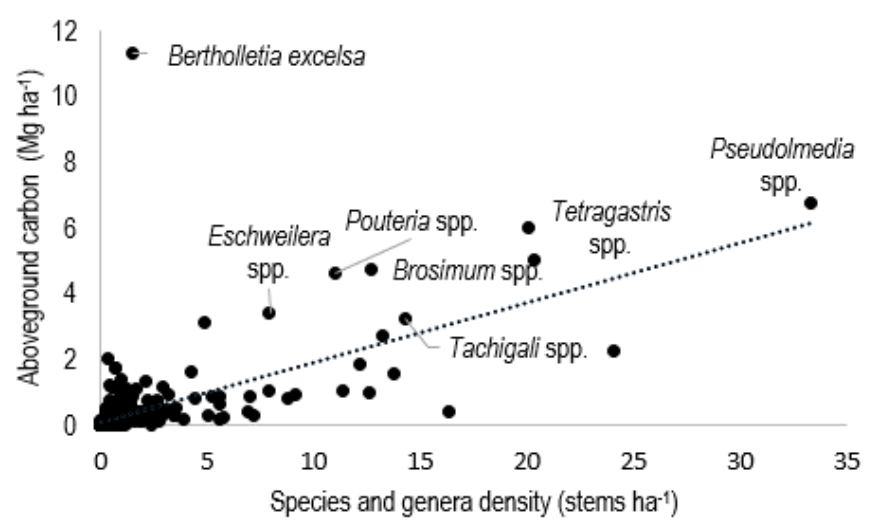

potential value of carbon stored in the plot network, the equivalent to US\$1328 is the aboveground $\mathrm{CO}_{2}$-eq value of economically important taxa utilized for commercial and livelihood purposes. Bertholletia excelsa alone has a $\mathrm{CO}_{2}$-eq value of US\$207 ha ${ }^{-1}$.

\section{DISCUSSION}

Economically important tree species $(>10 \mathrm{~cm} \mathrm{dbh})$ contribute significantly to forest structure and aboveground carbon storage 
Table 5. Welch tests $(\mathrm{F})$ for density $\left(\right.$ stems ha $\left.\mathrm{h}^{-1}\right)$, basal area $\left(\mathrm{m}^{2} \mathrm{ha}^{-1}\right)$, and aboveground carbon $\left(\mathrm{Mg} \mathrm{ha}^{-1}\right)$ of economically important nontimber and timber taxa grouped into dominant taxa ( $>$ two stems per hectare), common taxa (one to two stems per hectare), and rare taxa (fewer than one stem per hectare). Mean, standard error, degrees of freedom ( $\mathrm{df} 1$ and df 2 ), and significance at $\mathrm{p}<0.05$ per variable are shown. Values for minor and unknown use and unknown taxa were excluded from the analysis. Taxa were sampled in 41 1-ha permanent plots located in 19 terra firme and floodplain forests in southwestern Amazonia.

\begin{tabular}{|c|c|c|c|c|c|c|}
\hline Taxa density categories & Mean & Standard error & $\begin{array}{l}\text { Welch test } \\
\text { asymptotically F } \\
\text { distributed. }\end{array}$ & df1 & $\mathrm{df} 2$ & Sig \\
\hline \multicolumn{7}{|l|}{ Density (stems ha ${ }^{-1}$ ) } \\
\hline Dominant & 169 & 9.77 & 128.49 & 2 & 69.65 & 0.000 \\
\hline Common & 20 & 1.89 & & & & \\
\hline Rare & 45 & 2.70 & & & & \\
\hline \multicolumn{7}{|l|}{ Basal area $\left(\mathrm{m}^{2} \mathrm{ha}^{-1}\right)$} \\
\hline Dominant & 6 & 0.39 & 35.933 & 2 & 79.23 & 0.000 \\
\hline Common & 2 & 0.31 & & & & \\
\hline Rare & 4 & 0.37 & & & & \\
\hline \multicolumn{7}{|c|}{ Aboveground carbon $\left(\mathrm{Mg} \mathrm{ha}^{-1}\right)$} \\
\hline Dominant & 28 & 1.89 & 6.583 & 2 & 78.31 & 0.002 \\
\hline Common & 17 & 2.69 & & & & \\
\hline Rare & 28 & 2.33 & & & & \\
\hline
\end{tabular}

relative to taxa with minor or unknown economic use as inferred from 19 sites sampled in moist, submontane, terra firme and floodplain forest of southwestern Amazonia. The anthropogenic influence on these forests has received great attention in the last decade: ethnobotanical studies suggest that pre-Columbian peoples domesticated and dispersed at least 138 different crops for subsistence and trade, of which $68 \%$ were trees or woody perennials (Giux 2009, Scoles and Gribles 2011, Shepard and Ramirez 2011, Clement et al. 2015, Thomas et al. 2015, Levis et al. 2017). Other ethnobotanical studies in Madre de Dios, Peru reported $94 \%$ of woody stems in a 6.1 ha tree inventory to be useful (Phillips et al. 1994). In the same study, people indicated that $20 \%$ of species had commercial value and that $80 \%$ were used for subsistence. Thus, the potential contribution of ethnobotanical species to the economy and carbon stocks in southwestern Amazonia may be even higher than what we found in our study. Additionally, within economically important trees and palm taxa, there are key species that provide food for wildlife; these provide another reason to improve forest management.

Common and rare economic taxa contribute $35 \%$ of total aboveground carbon stocks versus $22 \%$ of that of the dominant class (Table 4). This follows mathematically from allometric equation (1) in which diameter has a much greater impact on aboveground carbon stocks estimation than wood density, especially for taxa with few stems at a high basal area. That said, low abundance is compensated by high basal areas in these taxa. The Brazil nut tree (B. excelsa) ranked first in terms of carbon storage, illustrating the dominant role of this economically important species for carbon stocks in forests of southwestern Amazonia. Fauset et al. (2015) ranked B. excelsa as the third most important species for Amazonian carbon stocks, which is clearly a very prominent role.

The question arises on how representative our sampled plots of southwestern Amazonian forests are, and how does our study reflect the abundance patterns of taxa and aboveground carbon, especially those with very important economic roles such as $B$. excelsa (Guariguata et al 2017). Forest types in the region are diverse because of elevation, geology, and climatic and soil differences, yet most of the region falls in the submontane range of 100-300 masl. Our sites represent evergreen seasonal forest with the presence of Guadua spp., which is typical of central and west, and also with a high abundance of Attalea spp. and Phenakospermum guyanense in the east of the region (Josse et al. 2007, Mostacedo et al. 2009, Navarro and Ferreira 2009, Salimon et al. 2011, Pintaud et al. 2016). Such forest types encompass sites in which $B$. excelsa is widely distributed, managed, and plays an important role in the economy ( $26 \%$ of total region area). Note that $65 \%$ of the total transboundary area has been classified as suitable for forest management and potentially includes $B$. excelsa (INRA 2008, IUCN 2008, Soliz 2009, Chávez et al. 2012, TEEB 2013). Unfortunately, high-quality inventories and extended sampling are still scarce in the region. Our results conservatively provide an indication of potential key species contributors to economy and carbon in at least three-quarters of the region, which is a very important regional portion.

How is it possible that $B$. excelsa plays such a prominent role in carbon stocks compared to the rest of economically important taxa and to taxa with minor or unknown use? The most obvious explanation is the population structure of the species, in which a high proportion of trees are in diameter classes above $40 \mathrm{~cm}$ (Peres et al. 2003, Zuidema 2003, Licona-Vasquez et al. 2010). This can be explained by the fact that the species is both emergent and long-lived (Camargo et al. 1994, Brienen and Zuidema 2006, Schöngart et al. 2015). It must also be noted that $B$. excelsa has the extra advantage by having a higher stem density than other emergent species, such as Ceiba spp. and Dipteryx spp. The density of $B$. excelsa $\left(1.5\right.$ stems $\left.^{-1}\right)$, in our study, is in the same ranges as found in other similar studies that did not follow a random and stratified sampling (Peres et al. 2003, Zuidema 2003, Nunes et al. 2012, Baraloto et al. 2015; Vaca, unpublished data). Note that only 4 of the 41 plots in this study overlap with those reported by Zuidema (2003). Our results also fall in the range of values obtained in a landscape-wide stratified sampling inventory in 
Table 6. Species and genera $(\mathrm{N}=62)$ with the highest aboveground carbon (AGC Mgha ${ }^{-1}$ ) values at a given density (stems per hectare). Taxa with major economic uses are timber $(\mathrm{T})$, food $(\mathrm{F})$, fruits $(\mathrm{A})$, construction, including thatching $(\mathrm{C})$, medicine $(\mathrm{M})$, handcrafts $(\mathrm{H})$, and as firewood $(\mathrm{F})$, latex $(\mathrm{L})$, between parenthesis if only locally used. Taxa were sampled in 41 permanent plots of 1 hectare each, located in 19 terra firme and floodplain forests in southwestern Amazonia (Killeen et al. 1993, Ledo 1996, TCA 1996, van Andel 2000, Duivenvoorden et al. 2001, Gutiérrez and Silva 2002, Ródriguez et al. 2002, Clavo et al. 2003, Mostacedo et al. 2003, Reynel et al. 2003, INFOBOL 2004, Dauber et al. 2005, Shanley and Medina 2005, Vargas et al. 2005, Thomas and Vandebroek 2006, Vieira et al. 2006, CPM 2008, Khan 2008, Cossio-Solano 2009, Obermüller et al. 2011, Moraes et al. 2014).

\begin{tabular}{|c|c|c|c|c|c|c|c|}
\hline Taxa & $\begin{array}{c}\text { Density (stems } \\
\text { ha }^{-1} \text { ) }\end{array}$ & $\begin{array}{c}\mathrm{AGC} \\
\left(\mathrm{Mg} \mathrm{ha}^{-1}\right)\end{array}$ & Use & Taxa & $\begin{array}{c}\text { Density (stems } \\
\text { ha }^{-1} \text { ) }\end{array}$ & $\begin{array}{c}\mathrm{AGC} \\
\left(\mathrm{Mg} \mathrm{ha}^{-1}\right)\end{array}$ & Use \\
\hline Bertholletia excelsa & 1.54 & 11.28 & 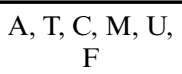 & Endopleura uchi & 0.80 & 0.75 & A \\
\hline Tetragastris altissima & 13.37 & 4.66 & $\mathrm{~T}$ & Hymenaea parvifolia & 0.51 & 0.72 & $\mathrm{~F}, \mathrm{~T}$ \\
\hline Pseudolmedia laevis & 21.27 & 4.27 & $(\mathrm{~T}),(\mathrm{A})$ & Celtis schippii & 4.17 & 0.72 & (A), $\mathrm{M}$ \\
\hline Iriartea deltoidea & 23.88 & 2.24 & $\mathrm{C}, \mathrm{A}, \mathrm{M}$ & Pourouma minor & 5.39 & 0.70 & $\mathrm{U}$ \\
\hline Eschweilera spp. & 3.85 & 1.99 & $\mathrm{C}$ & Swartzia spp. & 1.12 & 0.67 & $\mathrm{U}$ \\
\hline Brosimum lactescens & 5.51 & 1.72 & $\mathrm{~T}$ & Iryanthera juruensis & 7.61 & 0.65 & $\mathrm{~T}, \mathrm{C}$ \\
\hline Apuleia leiocarpa & 0.66 & 1.72 & $\mathrm{~T}$ & Castilla ulei & 1.27 & 0.65 & $\mathrm{~F}$ \\
\hline Tachigali spp. & 5.71 & 1.62 & $\mathrm{U}$ & Inga capitata & 1.93 & 0.64 & (A), F \\
\hline Pouteria spp. & 4.27 & 1.58 & (A) & Poulsenia armata & 0.90 & 0.61 & $\mathrm{U}, \mathrm{M}, \mathrm{C}$ \\
\hline Clarisia racemosa & 2.98 & 1.38 & $\mathrm{~T}$ & Brosimum alicastrum & 0.98 & 0.60 & (A) \\
\hline Eschweilera coriacea & 3.54 & 1.33 & $\mathrm{C}, \mathrm{M}$ & Tachigali polyphylla & 5.24 & 0.60 & $\mathrm{~T}, \mathrm{C}$ \\
\hline Tetragastris panamensis & 6.51 & 1.30 & $\mathrm{~T}$ & Geissospermum reticulatum & 0.59 & 0.56 & $\mathrm{U}$ \\
\hline Pseudolmedia laevigata & 6.49 & 1.28 & $(\mathrm{~T}),(\mathrm{A})$ & Parkia spp. & 0.29 & 0.56 & $\mathrm{~T}$ \\
\hline Pouteria torta & 2.46 & 1.23 & (A) & Dipteryx alata & 0.05 & 0.54 & $\mathrm{~T}, \mathrm{~F}, \mathrm{~A}$ \\
\hline Brosimum guianense & 3.12 & 1.22 & $\mathrm{~T},(\mathrm{~A})$ & Brosimum rubescens & 0.54 & 0.54 & $\mathrm{~T}$ \\
\hline Terminalia oblonga & 0.29 & 1.21 & $\mathrm{~T}$ & Enterolobium schomburgkii & 0.34 & 0.54 & $\mathrm{~T}$ \\
\hline Cedrelinga cateniformis & 0.49 & 1.16 & $\mathrm{~T}, \mathrm{M}$ & Aspidosperma macrocarpon & 0.22 & 0.51 & $\mathrm{~T}$ \\
\hline Inga spp. & 5.78 & 1.07 & $\mathrm{~A}, \mathrm{~F}$ & Gallesia integrifolia & 0.24 & 0.51 & $\mathrm{U}$ \\
\hline Couratari macrosperma & 0.56 & 1.06 & $\mathrm{~T}, \mathrm{C},(\mathrm{A})$ & Protium spp. & 3.83 & 0.50 & $\mathrm{~T}$ \\
\hline Chrysophyllum & 1.34 & 1.05 & $\mathrm{~T}, \mathrm{C}, \mathrm{M}$ & Pseudolmedia macrophylla & 2.41 & 0.50 & (A) \\
\hline \multicolumn{8}{|l|}{ venezuelanense } \\
\hline Dipteryx odorata & 0.12 & 0.99 & $\mathrm{~T}$ & Terminalia amazonia & 0.24 & 0.49 & $\mathrm{~T}, \mathrm{C}, \mathrm{F}$ \\
\hline Aspidosperma rigidum & 0.63 & 0.97 & $\mathrm{~T}$ & Pourouma spp. & 4.15 & 0.47 & $\mathrm{U}$ \\
\hline Peltogyne heterophylla & 1.39 & 0.84 & $\mathrm{~T}$ & Laetia procera & 0.76 & 0.47 & $\mathrm{U}$ \\
\hline Attalea butyracea & 5.66 & 0.82 & $\mathrm{C}, \mathrm{U}$ & Pouteria ephedrantha & 0.68 & 0.46 & $\mathrm{U}$ \\
\hline Astronium lecointei & 0.85 & 0.80 & $\mathrm{~T}, \mathrm{C}$ & Brosimum spp. & 2.05 & 0.44 & $\mathrm{~T}$ \\
\hline Cariniana micrantha & 0.22 & 0.80 & $\mathrm{U}$ & Pseudolmedia spp. & 2.22 & 0.44 & $\mathrm{~T}$ \\
\hline Cecropia sciadophylla & 4.07 & 0.79 & $\mathrm{~T}, \mathrm{C}$ & Diplotropis purpurea & 1.17 & 0.44 & $\mathrm{U}$ \\
\hline Siparuna decipiens & 10.49 & 0.78 & M & Heisteria nitida & 0.68 & 0.44 & $\mathrm{U}$ \\
\hline Dialium guianense & 1.29 & 0.77 & $\mathrm{~T}$ & Hevea brasiliensis & 0.98 & 0.43 & $\mathrm{~L}, \mathrm{~T}$ \\
\hline Ceiba pentandra & 0.22 & 0.77 & $\mathrm{~T}$ & Euterpe precatoria & 16.29 & 0.42 & A \\
\hline Leonia glycycarpa & 7.90 & 0.77 & $\mathrm{U}$ & Jacaranda copaia & 1.51 & 0.41 & $\mathrm{~T}$ \\
\hline
\end{tabular}

Pando (1.1 stems per ha ${ }^{-1}$ ) and in Acre (1.9 stems ha ${ }^{-1}$; DHV 1993, Wadt et al. 2005). The variation in density of $B$. excelsa across Amazonia is high and ranges from 26 stems to less than 1 stem per hectare (Salomão 1991, Zuidema 2003). Groves with more than 5.1 stems $\mathrm{ha}^{-1}$ of $B$. excelsa are not as frequent in southwestern Amazonia (Peres and Baider 1997).

For a long time, there have been discussions about the anthropogenic effect on density and conservation of B. excelsa trees in the Amazon. Ethnobotanical studies have shown a relationship between $B$. excelsa's presence close to human settlements that may explain, in part, the density pattern of the species (Giux 2009, Scoles and Gribel 2011, Thomas et al. 2014, Clement et al. 2015). The anthropogenic effect on B. excelsa may be also related to local peoples' economic decision of not felling large and productive stems of $B$. excelsa. In fact, the peak production in $B$. excelsa is at the large-diameter classes, i.e., 100 to $150 \mathrm{~cm}$ (Kainer et al. 2007; Vaca, unpublished data), compared to other commercial species, such as Copaifera spp., which can reach peak oil production at $70 \mathrm{~cm}$ diameter (Plowden 2004). It is also noteworthy that at a regional level, Brazilian, Bolivian, and Peruvian laws officially prohibit felling of $B$. excelsa trees given their long-term economic importance (Duchelle et al. 2011). The anthropogenic effect on $B$. excels $a$ is also related to nut harvesting intensities, suspected to cause the low frequency of regeneration cohorts and populations skewed to old senescent trees (Peres et al. 2003, Zuidema 2003, Wadt et al. 2008, Salo et al. 2014). That said, the influence of a single economically important species over carbon stocks in southwestern Amazonia depends on species intrinsic functional traits, but can also be influenced by anthropogenic use.

Timber taxa contribute greatly to carbon stocks in our study. This is because forest users harvest trees identified by a vernacular name or a genus-level name that sometimes involve several species. For example, Ficus spp., Inga spp., Protium spp., Virola spp., and Vochysia spp. each have at least six species in the study area (Cossio-Solano 2009). Rare, commercially important timber taxa 
Table 7. $\mathrm{CO}_{2}$-eq content $\left(\mathrm{Mg} \mathrm{ha}^{-1}\right.$ and $\left.\mathrm{US} \$ \mathrm{ha}^{-1}\right)$ of nontimber and timber species and genera grouped as dominant (taxa with $>$ two stems per hectare), common (taxa with one to two stems per hectare), and rare (taxa with fewer than one stem per hectare). Per-hectare absolute aboveground biomass (AGB), aboveground carbon (AGC), and $\mathrm{CO}_{2}$-eq values (absolute values divided by the number of sampled plots) are shown. Carbon fraction in biomass was estimated at 0.4735 (Martin and Thomas 2011), $\mathrm{CO}_{2}$-eq at 3.67 (IPCC 2000), and $\mathrm{CO}_{2}$-eq value at a reference price of US\$5 per Mg. Values for taxa of minor and unknown use and unknown taxa are shown. Taxa were sampled in 41 1-ha permanent plots located in terra firme and floodplain forests in southwestern Amazonia.

\begin{tabular}{|c|c|c|c|c|}
\hline Taxa density categories & $\begin{array}{c}\text { AGB } \\
\left(\mathrm{Mg} \mathrm{ha}^{-1}\right)\end{array}$ & $\begin{array}{c}\mathrm{AGC} \\
\left(\mathrm{Mg} \mathrm{ha}^{-1}\right)\end{array}$ & $\begin{array}{c}\mathrm{CO}_{2} \text {-eq } \\
\left(\mathrm{Mg} \mathrm{ha}^{-1}\right)\end{array}$ & $\begin{array}{c}\mathrm{CO}_{2} \text {-eq value } \\
\left(\mathrm{US} \$ \mathrm{ha}^{-1}\right)\end{array}$ \\
\hline \multicolumn{5}{|l|}{ Dominant } \\
\hline Species or genera primarily used for nontimber products & 13 & 6 & 23 & 113 \\
\hline Species or genera primarily used for timber products & 46 & 22 & 81 & 403 \\
\hline \multicolumn{5}{|l|}{ Common } \\
\hline Species or genera primarily used for nontimber products & 24 & 11 & 42 & 210 \\
\hline Species or genera primarily used for timber products & 11 & 5 & 19 & 97 \\
\hline \multicolumn{5}{|l|}{ Rare } \\
\hline Species or genera primarily used for nontimber products & 4 & 2 & 7 & 37 \\
\hline Species or genera primarily used for timber products & 54 & 26 & 94 & 468 \\
\hline Taxa with minor or unknown use & 108 & 51 & 187 & 935 \\
\hline Unknown taxa and use & 11 & 5 & 19 & 95 \\
\hline Total & 271 & 128 & 472 & 2358 \\
\hline
\end{tabular}

contribute more than dominant taxa to aboveground carbon stocks (Table 4). Rareness is a characteristic trait in Amazonian forests (Pitman et al. 2001, Schulze et al. 2008, Hubbell 2013). Our study suggests that rare species may be particularly vulnerable if these are affected by intensifying anthropogenic pressures such as selective logging (Giudice et al. 2012, Dablin 2014, Baraloto et al. 2015) and enhanced mortality due to climate change (Brienen et al. 2015). Brazil prohibits the harvest of trees at abundances lower than 0.03 stems ha ${ }^{-1}$ (Schulze et al. 2008). In Bolivia, restriction applies to $0.25 \mathrm{stems} \mathrm{ha}^{-1}$, yet above these thresholds, a common practice is to treat species equally. That is, the minimum cutting diameter and the retention of 10 to $20 \%$ of seed trees are applied irrespective of population structure. Precautionary measures are specifically recommended for Swietenia macrophylla, but much less so for other rare species. As a result, errors in estimating maximum harvesting limits because of poor species identification and erroneous timber estimation in forest inventories increase the chances of unsustainable yields and threaten the provision of the dual economic and environmental role of rare taxa.

The harvest intensity (volume extracted per hectare) can affect the recovery rate of aboveground biomass given the positive relationship between volume extraction and biomass recovery time (West et al. 2014). Low biomass recovery rates may occur if harvest intensity and cutting cycles are not harmonized with the demography and ecological requirements for regeneration after logging (seed dispersal and light demand among others) of each taxon. In our study, we found taxa with high commercial value, such as Ficus spp., Ceiba spp., Dipteryx spp., Cedrelinga cateniformis, Cariniana spp., and Terminalia oblonga, having an unbalanced population and distribution of stem sizes. These taxa had stems skewed to high-diameter classes with at least half of the population at sizes above $45 \mathrm{~cm}$ diameter and few stems in young categories (10 to $20 \mathrm{~cm}$ ). Some of these taxa, including nontimber B. excelsa, are already in threatened (i.e., vulnerable) categories of IUCN (2015) with data obtained at the landscape level. Studies on natural regeneration and recruitment are still scarce and the ones carried out in the region point out few important species mostly heliophytes being favored by the canopy openness, among them B. excelsa, Cedrela spp., Apuleia spp., and Couratari spp. (Myers et al. 2000, Parrota et al. 2002, Mostacedo et al. 2009). Note that our study is limited to trees with $\mathrm{dbh}>10$ $\mathrm{cm}$ as compared to other studies at minimum $\mathrm{dbh}>2.5 \mathrm{~cm}$ or regeneration sampling of seedlings $<1.3 \mathrm{~m}$ height. However, a study in a moist tropical forest of Panama found higher mortality rates in regeneration classes below $\mathrm{dbh}<10 \mathrm{~cm}$ than in those with $\mathrm{dbh}>10 \mathrm{~cm}$, especially in large species (Condit et al. 1995). Research should address regeneration of many more species, their light requirements, and responses to logging gaps to improve silvicultural prescriptions. Inventories may enhance their accuracy by sampling trees $<10 \mathrm{~cm}$ dbh coupled with floristic identification to predict species populations and carbon recovery over time.

Guidelines for forest management include a reduced impact logging to facilitate rapid recovery of forest (Putz et al. 2008a, $b$ ). For the southwestern Amazonian forest, where timber and Brazil nut trees are exploited, the logging intensity that modifies the environmental conditions for $B$. excelsa also needs to be addressed, because this species depends on a well-preserved forest to produce. A potential negative effect of increased logging intensity on Brazil nuts' productivity has been shown by Rockwell et al. 2015. A timber harvest limit of $5 \mathrm{~m}^{3} \mathrm{ha}^{-1}$ is prescribed to avoid damage to productive $B$. excelsa trees (Guariguata et al. 2009), but unfortunately, a lack of enforcement of maximum harvesting limits spells an uncertain future for Brazil nut trees and for other important economic species and species key for fauna. Additionally, uncertainty about the sustainability of Brazil nut harvests arises from the potential effect of nut collection on natural regeneration and the negative effect of frequent fires, habitat destruction, and drought on Brazil nut production.

The overall loss of forest economic value is the first step to landuse conversion and concomitant $\mathrm{CO}_{2}$ emissions. REDD+ has opened up the opportunity to value carbon stocks in tropical 
countries to compensate the low opportunity cost of forest-based economies through incentives for conservation and forest management. In Acre (Brazil) and Madre de Dios (Peru), projects are using the carbon market opportunity to generate incentives for conservation and recover economically valuable species and their carbon, including B. excelsa, Dipteryx odorata, Cedrelinga cateniformis, Euterpe precatoria, and Hevea brasiliensis (TEEB 2013, Bosques Amazónicos 2014, Duchelle et al. 2014b). The Bolivian government has rejected the carbon market approach but has created the Conjoint Mechanism for Climate Change Mitigation to support environmentally friendly initiatives (EPB 2012, Rouch 2015). REDD+ incentives are an opportunity for a rigorous revision and application of precautionary measures to adjust maximum harvesting limits and minimum cutting diameters at the species level to guarantee future yields, regeneration, and conservation of key species and their carbon in the southwestern Amazonian forest (van Gardingen et al. 2006, Schulze et al. 2008, Giudice et al. 2012, Rockwell et al. 2015). Permanent plots are a valuable tool to address growth, phenology, and mortality and to inform forest management and climate change mitigation policies.

\section{CONCLUSION}

Our study demonstrates that useful tree species in tropical forests have a dual role because they contribute considerably to both carbon storage and subsistence, especially those present in low abundance. In southwestern Amazonia, this dual role is presented most prominently by the Brazil nut tree, B. excelsa, which is exploited for nontimber forests products and accounts for around nine percent of the carbon stocks in forests in the region. This is a clear example of a synergy between economic gains and ecological function. Conserving and carefully managing stands of $B$. excelsa is not just important in terms of carbon stocks, but also because fruit production depends on the presence of an intact forest that harbors several other valuable species. Unplanned harvest can disrupt synergistic economic and environmental service roles altering carbon stocks temporarily or permanently. Maximum harvesting limits should address protection for $B$. excelsa populations, as has been the focus of other studies, but also prevent the extinction of other nontimber and timber valuable species by enforcing strict species-based extraction rules. Despite the controversy of market approach fairness to value ecosystem services of tropical forests, carbon stored in trees and palms already has a monetary value that is being channeled to early REDD+ initiatives in southwestern Amazonia. Precautionary measures based on species' ecology, demography, and regeneration traits should be at the forefront of REDD+ to reconcile sustainable yields and conservation of forest values to prevent emissions from land-use change and forest management.

Responses to this article can be read online at: http://www.ecologyandsociety.org/issues/responses. php/9297

\section{Acknowledgments:}

Financial support for this research came from the National Science Foundation, Coupled Natural and Human Systems Program, Grant
\#1114924. We also thank RAINFOR FORESTPLOTS.NET for information in forest plots. Thanks to students of Universidad Amazonica de Pando for field work participation.

\section{LITERATURE CITED}

Aragão, L. E. O. C., and Y. E. Shimabukuro, 2010. The incidence of fire in Amazonian forests with implications for REDD. Science 328:1275-1278. http://dx.doi.org/10.1126/science.1186925

Asner, G. P. 2009. Tropical forest carbon assessment: integrating satellite and airborne mapping approaches. Environmental Research Letters 4:1748-9326. http://dx.doi.org/10.1088/1748-9$\underline{326 / 4 / 3 / 034009}$

Baraloto, C., P. Alverga, S. Baéz Quispe, G. Barnes, N. Bejar Chura, I. Brasil da Silva, W. Castro, H. da Souza, I. de Souza Moll, J. Del Alcazar Chilo, H. Dueñas Linares, J. Garate Quispe, D. Kenji, H. Medeiros, S. Murphy, C. A. Rockwell, A. Shenkin, M. Silveira, J. Southworth, G. Vasquez, and S. Perz. 2014. Tradeoffs among forest value components in community forests of southwestern Amazonia. Ecology and Society 19(4):56. http://dx. doi.org/10.5751/es-06911-190456

Baraloto, C., P. Alverga, S. Baéz Quispe, G. Barnes, N. Bejar Chura, I. Brasil da Silva, W. Castro, H. da Souza, I. E. de SouzaMoll, J. del Alcazar Chilo, H. Dueñas Linares, J. Gárate Quispe, D. Kenji, M. Marsik, H. Medeiros, S. Murphy, C. Rockwell, G. Selaya, A. Shenkin, M. Silveira, J. Southworth, G. H. Vasquez Colomo, and S. Perz. 2015. Effects of road infrastructure on forest value across a tri-national Amazonian frontier. Biological Conservation 191:674-681. http://dx.doi.org/10.1016/j.biocon.2015.08.024

Bosques Amazónicos (BAM). 2014. REDD Project in Brazil nut concessions in Madre de Dios. Bosques Amazónicos, Madre de Dios, Peru. [online] URL: https://s3.amazonaws.com/CCBA/ Projects/REDD Project in Brazil Nut Concession in Madre de Dios/ Validation/Casta $\% \mathrm{C} 3 \% \mathrm{~B} 1$ eros $+\mathrm{REDD}+$ Project+CCB+PD+v6. pdf

Brienen, R. J. W., O. L. Phillips, T. R. Feldpausch, E. Gloor, T. R. Baker, J. Lloyd, G. Lopez-Gonzalez, A. MonteagudoMendoza, Y. Malhi, S. L. Lewis, R. Vásquez Martinez, M. Alexiades, E. Àlvarez Dávila, P. Alvarez Loayza, A. Andrade, L. E. O. C. Aragão, A. Araujo-Murakami, E. J. M. M. Arets, L. Arroyo, G. A. Aymard C., O. S. Bánki, C. Baraloto, J. Barroso, D. Bonal, R. G. A. Boot, J. L. C. Camargo, C. V. Castilho, V. Chama, K. J. Chao, J. Chave, J. A. Comiskey, F. Cornejo Valverde, L. da Costa, E. A. de Oliveira, A. Di Fiore, T. L. Erwin, S. Fauset, M. Forsthofer, D. R. Galbraith, E. S. Grahame, N. Groot, B. Hérault, N. Higuchi, E. N. Honorio Coronado, H. Keeling, T. J. Killeen, W. F. Laurance, S. Laurance, J. Licona, W. E. Magnussen, B. S. Marimon, B. H. Marimon-Junior, C. Mendoza, D. A. Neill, E. M. Nogueira, P. Núñez, N. C. Pallqui Camacho, A. Parada, G. Pardo-Molina, J. Peacock, M. Peña-Claros, G. C. Pickavance, N. C. A. Pitman, L. Poorter, A. Prieto, C. A. Quesada, F. Ramírez, H. Ramírez-Angulo, Z. Restrepo, A. Roopsind, A. Rudas, R. P. Salomão, M. Schwarz, N. Silva, J. E. Silva-Espejo, M. Silveira, J. Stropp, J. Talbot, H. ter Steege, J. Teran-Aguilar, J. Terborgh, R. Thomas-Caesar, M. Toledo, M. Torello-Raventos, R. K. Umetsu, G. M. F. van der Heijden, P. van der Hout, I. C. Guimarães Vieira, S. A. Vieira, E. Vilanova, V. A. Vos, and R. J. Zagt. 2015. Longterm decline of the Amazon carbon sink. Nature 519:344-348. http://dx.doi.org/10.1038/nature14283 
Brienen, R. J. W., and P. A. Zuidema. 2006. Lifetime growth patterns and ages of Bolivian rain forest trees obtained by tree ring analysis. Journal of Ecology 94:481-493. http://dx.doi. org/10.1111/j.1365-2745.2005.01080.X

Camargo, P. B., R. de P. Salomão, S. Trumbore, and L. A. Martinelli. 1994. How old are large Brazil-nut trees (Bertholletia excelsa) in the Amazon? Scientia Agricola 51:389-391. http://dx. doi.org/10.1590/S0103-90161994000200028

Chave, J., C. Andalo, S. Brown, M. A. Cairns, J. Q. Chambers, D. Eamus, H. Fölster, F. Fromard, N. Higuchi, T. Kira, J.-P. Lescure, B. W. Nelson, H. Ogawa, H. Puig, B. Riéra, and T. Yamakura. 2005. Tree allometry and improved estimation of carbon stocks and balance in tropical forest. Oecologia 145:87-99. http://dx.doi. org/10.1007/s00442-005-0100-X

Chave, J., M. Réjou-Méchain, A. Búrquez, E. Chidumayo, M. S. Colgan, W. B. C. Delitti, A. Duque, T. Eid, P. M. Fearnside, R. C. Goodman, M. Henry, A. Martínez-Yrízar, W. A. Mugasha, H. C. Mullerlandau, M. Mencuccini, B. W. Nelson, A. Ngomanda, E. M. Nogueira, E. Ortiz-Malavassi, R. Pélissier, P. Ploton, C. M. Ryan, J. G. Saldarriaga, and G. Vieilledent. 2014. Improved allometric models to estimate the aboveground biomass of tropical trees. Global Change Biology 20:3177-3190. http://dx.doi. org/10.1111/gcb. 12629

Chávez, A., M. Guariguata, P. Cronkleton, M. Menton, J. L. Capella, J. P. Araujo, and J. Quaedvlieg. 2012. Superposición espacial en la zonificación de bosques en Madre de Dios: implicaciones para la sostenibilidad del recurso castañero. CIFOR InfoBrief No. 54. Center for International Forestry Research, Bogor, Indonesia. [online] URL: http://www.cifor.org/publications/ pdf_files/infobrief/4034-infobrief.pdf

Clavo, P. Z. M, C. Z. P. Seijas, and O. J. Alegre. 2003. Plantas medicinales usadas por mujeres nativas y mestizas en la región Ucayali. IVITA-INIA-ICRAF, Pucallpa, Peru.

Clement, C. R., W. M. Denevan, M. J. Heckenberger, A. B. Junqueira, E. G. Neves, W. G. Teixeira, and W. I. Woods. 2015. The domestication of Amazonia before European conquest. Proceedings of the Royal Society B 282:20150813. http://dx.doi. org/10.1098/rspb.2015.0813

Condit, R., S. P. Hubbel, and R. B. Foster. 1995. Mortality rates of 205 neotropical tree and shrub species and the impact of a severe drought. Ecological Monographs 65(4):419-439. http://dx. doi.org/10.2307/2963497

Confederación Peruana de Madera (CMP). 2008. Compendio de información técnica de 32 especies forestales. Tomo II. Confederación Peruana de Madera, Lima, Peru.

Cossio-Solano, R. E. 2009. Capacity for timber management among private small-medium forest enterprises in Madre de Dios, Peru. Dissertation. University of Florida, Gainesville, Florida, USA. [online] URL: $\underline{\text { http://ufdc.ufl.edu/UFE0024380/00001 }}$

Cummings, D. L., J. B. Kauffman, D. A. Perry, and R. F. Hughes. 2002. Aboveground biomass and structure of rainforests in the southwestern Brazilian Amazon. Forest Ecology and Management 163:293-307. http://dx.doi.org/10.1016/S0378-1127(01)00587-4
Dablin, L. J. 2014. Assessing the drivers of forest loss in Madre de Dios, Peru. Thesis. Imperial College, London, UK. [online] URL: http://www.iccs.org.uk/wp-content/uploads/2011/10/ Dablin_Lucy_ConSci_2014.pdf

Daly, D. C., and M. Silveira. 2008. Primeiro catálogo da flora do Acre, Brasil. Universidad Federal do Acre (UFAC), Rio Branco, Acre, Brazil.

Dauber, E., T. S. Fredericksen, and M. Peña. 2005. Sustainability of timber harvesting in Bolivian tropical forest. Forest Ecology and Management 214:284-304. http://dx.doi.org/10.1016/j. foreco.2005.04.019

DHV Consultores. 1993. Estudios agro-ecológicos, forestales y socio-económicos en la región de la castaña de la Amazonia Boliviana. Forest Resource Inventory. Banco Mundial, Gobierno de Holanda, Amersfoort.

DHV Consultores. 1997. Zonificación agroecológica y socioeconómica y perfil ambiental del departamento de Pando. ZONISIG proyecto zonificación agro-ecológica y establecimiento de una base de datos y red de sistema de información Geográfica en Bolivia. Ministerio de Desarrollo Sostenible y Medio Ambiente, La Paz, Bolivia. [online] URL: http://www.bivica.org/ upload/zonificacion_pando.pdf

Duchelle, A. E., P. Cronkleton, K. A. Kainer, G. Guanacoma, and S. Gezan. 2011. Resource theft in tropical forest communities: implications for non-timber management, livelihoods, and conservation. Ecology and Society 16(1):4. http://dx.doi. org/10.5751/es-03806-160104

Duchelle, A. E., A. M. Almeyda-Zambrano, S. Wunder, J. Börner, and K. A. Kainer. 2014a. Smallholder specialization strategies along the forest transition curve in Southwestern Amazonia. World Development 64:149-158. https://doi.org/10.1016/j. worlddev.2014.03.001

Duchelle, A. E., M. Greenleaf, D. Mello, M. F. Gebara, and T. Melo, 2014b. Acre's state system of incentives for environmental services (SISA), Brazil. Pages 31-50 in E. O. Sills, S. Atmadja, C. de Sassi, A. E. Duchelle, D. Kweka, I. A. P. Resosudarmo, and W. D. Sunderlin, editors. REDD+ on the ground: a case book of subnational initiatives across the globe. Center for International Forestry Research, Bogor, Indonesia.

Duivenvoorden, J. F., H. Balslev, J. Cavelier, H. Grandez, C. Tuomisto, and R. Valencia. 2001. Evaluación de recursos vegetales no maderables en la Amazonía noroccidental. Institute for Biodiversity and Ecosystem Dynamics, Amsterdam, The Netherlands.

Encarnación, F., R. Zarate, and M. Ahuite. 2008. Zonificación ecológica y económica del departamento de Madre de Dios. Vegetación. Gobierno Regional de Madre de Dios-Instituto de Investigaciones de la Amazonia Peruana, Madre de Dios, Peru.

Escobedo, T. R. 2008. Zonificación ecológica y económica del departamento de Madre de Dios. Fisiografía. Gobierno Regional de Madre de Dios-Instituto de Investigaciones de la Amazonia Peruana, Madre de Dios, Peru.

Estado Plurinacional de Bolivia (EPB). 2012. Mecanismo conjunto de mitigación y adaptación para el manejo integral y 
sustentable de los bosques y la Madre Tierra. Estado Plurinacional de Bolivia, La Paz, Bolivia. [online] URL: http:// www.alainet.org/es/active/57645

Fauset, S., M. O. Johnson, M. Gloor, T. R. Baker, A. Monteagudo M., R. J. W. Brienen, T. R. Feldpausch, G. Lopez-Gonzalez, Y. Malhi, H. ter Steege, N. C. A. Pitman, C. Baraloto, J. Engel, P. Pétronelli, A. Andrade, J. L. C. Camargo, S. G. W. Laurance, W. F. Laurance, J. Chave, E. Allie, P. Núñez Vargas, J. W. Terborgh, K. Ruokolainen, M. Silveira, G. A. Aymard C., L. Arroyo, D. Bonal, H. Ramirez-Angulo, A. Araujo-Murakami, D. Neill, B. Hérault, A. Dourdain, A. Torres-Lezama, B. S. Marimon, R. P. Salomão, J. A. Comiskey, M. Réjou-Méchain, M. Toledo, J. C. Licona, A. Alarcón, A. Prieto, A. Rudas, P. J. van der Meer, T. J. Killeen, B.-H. Marimon Junior, L. Poorter, R. G. A. Boot, B. Stergios, E. Vilanova Torre, F. R. C. Costa, C. Levis, J. Schietti, P. Souza, N. Groot, E. Arets, V. Chama Moscoso, W. Castro, E. N. Honorio Coronado, M. Peña-Claros, C. Stahl, J. Barroso, J. Talbot, I. C. Guimarães Vieira, G. van der Heijden, R. Thomas, V. A. Vos, E. C. Almeida, E. Alvarez Davila, L. E. O. C. Aragão, T. L. Erwin, P. S. Morandi, E. Almeida de Oliveira, M. B. X. Valadão, R. J. Zagt, P. van der Hout, P. Alvarez Loayza, J. J. Pipoly, O. Wang, M. Alexiades, C. E. Cerón, I. HuamantupaChuquimaco, A. Di Fiore, J. Peacock, N. C. Pallqui Camacho, R. K. Umetsu, P. Barbosa de Camargo, R. J. Burnham, R. Herrera, C. A. Quesada, J. Stropp, S. A. Vieira, M. Steininger, C. Reynel Rodríguez, Z. Restrepo, A. Esquivel Muelbert, S. L. Lewis, G. C. Pickavance, and O. L. Phillips. 2015. Hyperdominance in Amazonian forest carbon cycling. Nature Communications 6:6857. http://dx.doi.org/10.1038/ncomms7857

Foley, J. A., G. P. Asner, M. Heil-Costa, M. T. Coe, R. DeFries, H. K. Gibbs, E. A. Howard, S. Olson, J. Patz, N. Ramankutty, and P. Snyder. 2007. Amazonia revealed: forest degradation and loss of ecosystem goods and services in the Amazon Basin. Frontiers in Ecology and the Environment 5:25-32. [online] URL: http://water.columbia.edu/files/2011/11/DeFries2007Amazonia.pdf

Giudice, R., B. S. Soares-Filho, F. Merry, H. O. Rodrigues, and M. Bowman. 2012. Timber concessions in Madre de Dios: are they a good deal? Ecological Economics 77:158-165. http://dx.doi. org/10.1016/j.ecolecon.2012.02.024

Giux, J. C. 2009. Amazonian forests need Indians and Caboclos. Orsis 24:33-40. [online] URL: http://www.raco.cat/index.php/ Orsis/article/download/181223/233874

Goodman, R. C., O. L., Phillips, and T. R. Baker. 2014. The importance of crown dimensions to improve tropical tree biomass estimates. Ecological Applications 24:680-698. http://dx.doi. org/10.1890/13-0070.1

Goodman, R. C., O. L. Phillips, D. del Castillo Torres, L. Freitas, S. T. Cortese, A. Monteagudo, and T. R. Baker. 2013. Amazon palm biomass and allometry. Forest Ecology and Management 310:994-1004. http://dx.doi.org/10.1016/j.foreco.2013.09.045

Guariguata, M. R., J. C. Licona, B. Mostacedo, and P. Cronkleton. 2009. Damage to Brazil nut trees (Bertholletia excelsa) during selective timber harvesting in Northern Bolivia. Forest Ecology and Management 258:788-793. http://dx.doi. org/10.1016/j.foreco.2009.05.022
Guariguata, M. R., P. Cronkleton, A. E. Duchelle, and P. A Zuidema. 2017. Revisiting the 'cornerstone of Amazonian conservation': a socioecological assessment of Brazil nut exploitation. Biodiversity Conservation. http://dx.doi.org/10.1007/ $\underline{\text { s10531-017-1355-3 }}$

Gutiérrez-Rojas, V. H., and J. Silva Sandoval. 2002. Información técnica para el procesamiento industrial de 134 especies maderables de Bolivia. Serie Técnica XII. Ministerio de Desarrollo Sostenible y Planificación and Instituto Brasileiro do Medio Ambiente e dos Recursos Naturais Renováveis, La Paz, Bolivia.

Hubbell, S. B. 2013. Tropical rain forest conservation and the twin challenges of diversity and rarity. Ecology and Evolution 3:3263-3274. http://dx.doi.org/10.1002/ece3.705

INFOBOL. 2004. Especies forestales reportadas en los bosques tropicales de Bolivia. Inventario forestal nacional y programa de control de los recursos forestales de Bolivia. Ministerio de Asuntos Campesinos y Agropecuarios (MACA), La Paz, Bolivia. [online] URL: http://www.itto.int/files/itto_project_db_input/2122/Technical/ DOCUMENTO \%20ESPECIES \%20INFOBOL.pdf

Instituto Brasileiro de Geografia e Estatística (IBGE). 2012. Manual técnico da vegetação Brasileira. Sistema fitogeográico inventário das formações florestais e campestres. Técnicas e manejo de coleções botânicas. Procedimentos para mapeamentos. Instituto Brasileiro de Geografia e Estatística, Rio de Janeiro, Brasil.

Instituto Nacional de Reforma Agraria (INRA). 2008. Pando tierra saneada con la reconducción comunitaria. Instituto Nacional de Reforma Agraria, Pando, Bolivia. [online] URL: http://www. inra.gob.bo/InraPb/upload/LibroPando.pdf

International Tropical Timber Organization (ITTO). 2016. Tropical timber. Lesser used species. International Tropical Timber Organization, Yokohama, Japan. [online] URL: http:// www.tropicaltimber.info/

International Union for Conservation of Nature (IUCN). 2008. Supporting local forest use in Amazonian Brazil: the Chico Mendes Extractive Reserve. Forest Conservation Programme. International Union for Conservation of Nature, Gland, Switzerland. [online] URL: https://cmsdata.iucn.org/downloads/rubber story.pdf

International Union for Conservation of Nature (IUCN). 2015. Red list. International Union for Conservation of Nature, Gland, Switzerland. [online] URL: http://www.iucnredlist.org

Josse, C., G. Navarro, F. F. Encarnación, A. Tovar, P. Comer, W. Ferreira, F. Rodríguez, J. Saito, J. Sanjurjo, J. Dyson, E. Rubin de Celis, R. Zárate, J. Chang, M. Ahuite, C. Vargas, F. Paredes, W. Castro, J. Maco, and F. Reátegui. 2007. Sistemas ecológicos de la Cuenca Amazónica de Peruy Bolivia. Clasificación y mapeo. NatureServe, Arlington, Virginia, USA.

Kainer, K. A., L. H. O. Wadt, and C. L. Staudhammer. 2007. Explaining variation in Brazil nut fruit production. Forest Ecology and Management 250:244-255. http://dx.doi.org/10.1016/j. foreco.2007.05.024

Kainer, K. A., L. H. O. Wadt, and C. L. Staudhammer. 2014. Testing a silvicultural recommendation: Brazil nut responses 10 years after liana cutting. Journal of Applied Ecology 51:655-663. http://dx.doi.org/10.1111/1365-2664.12231 
Khan, F. 2008. The genus Astrocaryum (Arecaceae). Revista Peruana de Biología 15:31-48. [online] URL: http://www.scielo. org.pe/scielo.php?script=sci_pdf\&pid=S1727-99332008000000004\&lng= es\&nrm=iso\&tlng=en

Killeen, T. J., E. García E., and S. G. Beck. 1993. Guía de árboles de Bolivia. Herbario Nacional de Bolivia, La Paz, Bolivia, y Missouri Botanical Garden, St. Louis, Missouri, USA. [online] URL: http://pdf.usaid.gov/pdf docs/pnaca189.pdf

Ledo, A. da S. 1996. Potencialidade da fruticultura no estado do Acre. Empresa Brasileira de Pesquisa Agropecuária Ministério da Agricultura, Pecuária e Abastecimento (EMBRAPA), Brasília, Brazil. [online] URL: https://www.embrapa.br/buscade-publicacoes/-/publicacao/492647/potencialidade-da-fruticulturano-estado-do-acre

Levis, C., F. R. C. Costa, F. Bongers, M. Peña-Claros, C. R. Clement, A. B. Junqueira, E. G. Neves, E. K. Tamanaha, F. O. G. Figueiredo, R. P. Salomão, C. V. Castilho, W. E. Magnusson, O. L. Phillips, J. E. Guevara, D. Sabatier, J.-F. Molino, D. Cárdenas López, A. M. Mendoza, N. C. A. Pitman, A. Duque, P. Núñez Vargas, C. E. Zartman, R. Vasquez, A. Andrade, J. L. Camargo, T. R. Feldpausch, S. G. W. Laurance, W. F. Laurance, T. J. Killeen, H. E. MendonÃ §a Nascimento, J. C. Montero, B. Mostacedo, I. L. Amaral, I. C. Guimarães Vieira, R. Brienen, H. Castellanos, J. Terborgh, M. de Jesus Veiga Carim, J. R. da Silva Guimarães, L. de Souza Coelho, F. D. de Almeida Matos, F. Wittmann, H. F. Mogollón, G. Damasco, N. Dávila, R. GarcíaVillacorta, E. N. H. Coronado, T. Emilio, D. de Andrade Lima Filho, J. Schietti, P. Souza, N. Targhetta, J. A. Comiskey, B. S. Marimon, B.-H. Marimon, Jr., D. Neill, A. Alonso, L. Arroyo, F. A. Carvalho, F. C. de Souza, F. Dallmeier, M. P. Pansonato, J. F. Duivenvoorden, P. V. A. Fine, P. R. Stevenson, A. AraujoMurakami, G. A. Aymard C., C. Baraloto, D. D. do Amaral, J. Engel, T. W. Henkel, P. Maas, P. Petronelli, J. D. Cardenas Revilla, J. Stropp, D. Daly, R. Gribel, M. Ríos Paredes, M. Silveira, R. Thomas-Caesar, T. R. Baker, N. F. da Silva, L. V. Ferreira, C. A. Peres, M. R. Silman, C. Cerón, F. C. Valverde, A. Di Fiore, E. M. Jimenez, M. C. Peñ uela Mora, M. Toledo, E. M. Barbosa, L. C. de Matos Bonates, N. C. Arboleda, E. de Sousa Farias, A. Fuentes, J.-L. Guillaumet, P. Møller Jørgensen, Y. Malhi, I. P. de Andrade Miranda, J. F. Phillips, A. Prieto, A. Rudas, A. R. Ruschel, N. Silva, P. von Hildebrand, V. A. Vos, E. L. Zent, S. Zent, B. B. L. Cintra, M. T. Nascimento, A. A. Oliveira, H. Ramirez-Angulo, J. F. Ramos, G. Rivas, J. Schöngart, R. Sierra, M. Tirado, G. van der Heijden, E. V. Torre, O. Wang, K. R. Young, C. Baider, A. Cano, W. Farfan-Rios, C. Ferreira, B. Hoffman, C. Mendoza, I. Mesones, A. Torres-Lezama, M. N. U. Medina, T. R. van Andel, D. Villarroel, R. Zagt, M. N. Alexiades, H. Balslev, K. GarciaCabrera, T. Gonzales, L. Hernandez, I. HuamantupaChuquimaco, A. G. Manzatto, W. Milliken, W. P. Cuenca, S. Pansini, D. Pauletto, F. R. Arevalo, N. F. Costa Reis, A. F. Sampaio, L. E. Urrego Giraldo, E. H. Valderrama Sandoval, L. Valenzuela Gamarra, C. I. A. Vela, and H. ter Steege. 2017. Persistent effects of pre-Columbian plant domestication on Amazonian forest composition. Science 355, 925-931. http://dx. doi.org/10.1126/science.aal0157

Lewis, S. L., P. M. Brando, O. L. Phillips, G. M. F. van der Heijden, and D. Nepstad. 2011. The 2010 Amazon drought. Science 331 (6017):554. http://dx.doi.org/10.1126/science.1200807
Licona-Vasquez, J. C., B. Mostacedo, Z. Villegas, O. Rodríguez, and Y. Bustamante. 2010. Monitoreo de castaña (Bertholletia excelsa) a través de parcelas permanentes en la Reserva Nacional de Vida Silvestre Amazónica Manuripi, Pando -Bolivia. Instituto Boliviano de Investigación Forestal/Fondo Mundial para la Naturaleza, Santa Cruz, Bolivia.

Londono, X., and P. M. Peterson. 1991. Guadua sarcocarpa (Poaceae: Bambuseae), a new species of Amazonian bamboo with fleshy fruits. Systematic Botany 16:630-638. http://dx.doi. org/10.2307/2418866

Marengo, J. A., C. A. Nobre, J. Tomasella, M. D. Oyama, G. Sampaio de Oliveira, R. de Oliveira, H. Camargo, L. M. Alves, and I. F. Brown. 2008. The drought of Amazonia in 2005. Journal of Climate 21:495-516. http://dx.doi.org/10.1175/2007JCLI1600.1

Martin, A. R., and S. C. Thomas. 2011. A reassessment of carbon content in tropical trees. PLoS ONE 6(8):e23533. http://dx.doi. org/10.1371/journal.pone.0023533

McDonald, J. H. 2014. Handbook of biological statistics. Sparky House Publishing, Baltimore, Maryland, USA. http://www. biostathandbook.com/index.html

Moraes R., M. 2014. Palmeras útiles de Bolivia, las especies mayormente aprovechadas para diferentes fines y aplicaciones. Herbario Nacional de Bolivia, Universidad Mayor de San Andrés, Plural Editores, La Paz, Bolivia.

Mori, S. A., and G. T. Prance. 1998. Taxonomy, ecology, and economic botany of the Brazil nut (Bertholletia excelsa Humb. and Bonpl.:Lecythidaceae). Advances in Economic Botany 8:130-150. [online] URL: https://www.researchgate.net/

publication/259658475 Taxonomy ecology and economic botany of the Brazil_nut Bertholletia_excelsa_Humb_BonplLecythidaceae

Mostacedo B., J. Justiniano, M. Toledo, and T. Fredericksen. 2003. Guía dendrológica de especies forestales de Bolivia. Second edition. BOLFOR, Santa Cruz, Bolivia.

Mostacedo, B., Z. Villegas, J. C. Licona, A. Alarcon, D. Villarroel, M. Peña-Claros, and T. S. Fredericksen. 2009. Bosque Amazónico. Pages 82-102 in Ecología y silvicultura de los principales bosques tropicales de Bolivia. Instituto Boliviano de Investigacion Forestal (IBIF), Santa Cruz, Bolivia. [online] URL: https://www.researchgate.net/publication/261063315 Ecologia y_Silvicultura de los_Principales_Bosques_Tropicales de_Bolivia

Myers, G. P., A. C. Newton, and O. Melgarejo. 2000. The influence of canopy gap size on natural regeneration of Brazil nut (Bertholletia excelsa) in Bolivia. Forest Ecology and Management 127:119-128. http://dx.doi.org/10.1016/S0378-1127(99)00124-3

Navarro, G., and W. Ferreira. 2009. Informe final de consultoría técnica para herencia: vegetación y unidades ambientales del norte amazónico de Bolivia. RUMBOL, Cochabamba, Bolivia.

Nunes, F., B. Soares-Filho, R. Giudice, H. Rodrigues, M. Bowman, R. Silvestrini, and E. Mendoza. 2012. Economic benefit of forest conservation: assessing the potential rents from Brazil nut concessions in Madre de Dios, Peru, to channel REDD+ investments. Environmental Conservation 39:132-143. http://dx. doi.org/10.1017/S0376892911000671 
Obermüller, F. A., D. C. Daly, E. C. Oliveira, H. F. T. P. Sousa, H. M. de Oliveira, L. S. Souza, and M. Silveira. 2011. Guía ilustrada e manual de arquitetura foliar para espécies. madeireiras de amazônia ocidental. G. K. Noronha, Río Branco, Brazil. [online] URL: https://ppbio.inpa.gov.br/sites/default/files/Guia\% 20e $\% 20$ Manual $\% 20$ Arquitetura $\% 20$ foliar.pdf

Osuri, A. M., J. Ratnam, V. Varma, P. Alvarez-Loayza, J. Hurtado Astaiza, M. Bradford, C. Fletcher, M. Ndoundou-Hockemba, P. A. Jansen, D. Kenfack, A. R. Marshall, B. R. Ramesh, F. Rovero, and M. Sankaran. 2016. Contrasting effects of defaunation on aboveground carbon storage across the global tropics. Nature Communications 7:4-25. http://dx.doi.org/10.1038/ncomms11351

Parrotta, J. A., J. K. Francis, and O. H. Knowles. 2002. Harvesting intensity affects forest structure and composition in an upland Amazonian forest. Forest Ecology and Management 169:243-255. http://dx.doi.org/10.1016/S0378-1127(01)00758-7

Peres, C. A., and C. Baider. 1997. Seed dispersal, spatial distribution and population structure of Brazil nut trees (Bertholletia excelsa) in southeastern Amazonia. Journal of Tropical Ecology 13:595-616. http://dx.doi.org/10.1017/ $\underline{\mathrm{S} 0266467400010749}$

Peres, C. A., C. Baider, P. A. Zuidema, L. H. O. Wadt, K. A. Kainer, D. A. P. Gomes-Silva, R. P. Salomão, R. P. Simões, E. R. N. Franciosi, F. Cornejo Valverde, R. Gribel, G. H. Shepard, Jr., M. Kanashiro, P. Coventry, D. W. Yu, A. R. Watkinson, and R. P. Freckleton. 2003. Demographic threats to the sustainability of Brazil nut exploitation. Science 302:2112-2114. http://dx.doi. org/10.1126/science.1091698

Perz, S. G., Y. Qiu, Y. Xia, J. Southworth, J. Sun, M. Marsik, K. Rocha, V. Passos, D. Rojas, G. Alarcón, G. Barnes, and C. Baraloto. 2013. Trans-boundary infrastructure and land cover change: highway paving and community-level deforestation in a tri-national frontier in the Amazon. Land Use Policy 34:27-41. http://dx.doi.org/10.1016/j.landusepol.2013.01.009

Peters-Stanley, M., and G. Gonzalez. 2014. Sharing the stage: state of the voluntary Carbon Markets 2014. Forest Trends Ecosystem Marketplace, Washington D.C., United States. [online] URL: http://www.forest-trends.org/vem2014.php

Pfaff, A., J. Robalino, R. Walker, S. Aldrich, M. Caldas, E. Reis, S. Perz, C. Bohrer, E. Arima, W. Laurance, and K. Kirby. 2007. Road investments, spatial spillovers, and deforestation in the Brazilian Amazon. Journal of Regional Science 47:109-123. http:// dx.doi.org/10.1111/j.1467-9787.2007.00502.X

Phillips O., T. Baker, T. Feldpausch, and R. Brienen. 2009. RAINFOR manual de campo para la remedición y establecimiento de parcelas RAINFOR, University of Leeds, Leeds, UK. [online] URL: http://www.rainfor.org/upload/ManualsSpanish/Manual/ RAINFOR_field_manual_version2016_ES.pdf

Phillips, O., A. H. Gentry, C. Reynel, P. Wilkin, and C. GalvezDurand B. 1994. Quantitative ethnobotany and Amazonian conservation. Conservation Biology 8:225-248. http://dx.doi. org/10.1046/j.1523-1739.1994.08010225.x

Pintaud, J.-C., A. M. Rodriguez del Castillo, E. J. L. Ferreira, M. Moraes, and K. Mejía. 2016. Towards a revision of Attalea in Western Amazonia. Palms 60(2):57-77. [online] URL: http:// www.perou.ird.fr/content/download/249362/3797537/version/1/file/ Pintaud+et+al++Attalea+SW+Amazonia+2016+Palms.pdf

Pitman, N. C. A., J. W. Terborgh, M. R. Silman, P. Núñez V., D. A. Neill, C. E. Cerón, W. A. Palacios, and M. Aulestia. 2001. Dominance and distribution of tree species in upper Amazonian terra firme forests. Ecology 82:2101-2117. http://dx.doi. org/10.1890/0012-9658(2001)082[2101:DADOTS]2.0.CO;2

Plowden, C. 2004. The ethnobotany of copaíba (copaifera) oleoresin in the amazoil. Economic Botany 58:729-733. http://dx. doi.org/10.1663/0013-0001(2004)058[0729:TEOCCO]2.0.CO;2

Putz, F. E., P. Sist, T. Fredericksen, and D. Dykstra. 2008a. Reduced-impact logging: challenges and opportunities. Forest ecology and Management 256:1427-1433. http://dx.doi. org/10.1016/j.foreco.2008.03.036

Putz, F. E., P. A. Zuidema, M. A. Pinard, R. G. A. Boot, J. A. Sayer, D. Sheil, P. Sist, Elias, and J. K. Vanclay. 2008b. Improved tropical forest management for carbon retention. PLoS Biology 6:e166. http://dx.doi.org/10.1371/journal.pbio.0060166

Putz, F. E., P. A. Zuidema, T. Synnott, M. Peña-Claros, M. A. Pinard, D. Sheil, J. K. Vanclay, P. Sist, S. Gourlet-Fleury, B. Griscom, J. Palmer, and R. Zagt. 2012. Sustaining conservation values in selectively logged tropical forests: the attained and the attainable. Conservation Letters 5:296-303. http://dx.doi. org/10.1111/j.1755-263X.2012.00242.X

Reynel, C., T. D. Pennington, C. Flores, and A. Daza. 2003. Árboles útiles de la Amazonía Peruana y sus usos, un manual con apuntes de identificación, ecología y propagación de las especies. Herbario de la Facultad de Ciencias Forestales de la Universidad Nacional Agraria, La Molina, Royal Botanic Gardens Kew, Royal Botanic Gardens Edinburgh, ICRAF. [online] URL: https://www.slideshare.net/educador23013/arboles-utiles-de-la-amazoniaperuana

Rockwell, C. A., M. R. Guariguata, M. Menton, E. Arroyo Quispe, J. Quaedvlieg, E. Warren-Thomas, H. Fernandez Silva, E. E. Jurado Rojas, J. A. Hideki Kohagura Arrunátegui, L. A. Meza Vega, O. Revilla Vera, R. Quenta Huancco, J. F. Valera Tito, B. T. Villarroel Panduro, and J. J. Yucra Salas. 2015. Nut production in Bertholletia excelsa across a logged forest mosaic: implications for multiple forest use. PLoS ONE 10(8):e0135464. http://dx.doi.org/10.1371/journal.pone.0135464

Ródriguez, J., S. Beck, R. Seidel, S. Villavicencio, J. L. Crespo, A. Pinto, A. Ticona, W. Steiner, F. Morales, D. Chairiqui, and A. Caimani. 2002. Guía de especies forestales del Alto Beni, programa de implementaciones agroecológicas y forestales. PIAF-ElCEIBO, Sapecho, Bolivia.

Rouch, S. 2015. Putting a price on nature can benefit the poor if done right. SciDev. Net 20 January. http://www.scidev.net/global/ environment/feature/price-nature-poor-eco-management.html\#sthash. aBqZGCvf.dpuf

Saatchi, S. S., N. L. Harris, S. Brown, M. Lefsky, E. T. A. Mitchard, W. Salas, B. R. Zutta, W. Buermann, S. L. Lewis, S. Hagen, S. Petrova, L. White, M. Silman, and A. Morel. 2011. Benchmark map of forest carbon stocks in tropical regions across three continents. Proceedings of the National Academy of Sciences 108 (24):9899-9904. http://dx.doi.org/10.1073/pnas.1019576108 
Salimon, C. I., F. E. Putz, L. Menezes-Filho, A. Anderson, M. Silveira, I. F. Brown, and L. C. Oliveira. 2011. Estimating statewide biomass carbon stocks for a REDD plan in Acre, Brazil. Forest Ecology and Management 262:555-560. http://dx.doi. org/10.1016/j.foreco.2011.04.025

Salo, M., A. Sirén, and R. Kalliola. 2014. Diagnosis wild species harvest: resource use and conservation. Elsevier, Atlanta, Georgia, USA.

Salomão, R. P. 1991. Estrutura e densidade de Bertholletia excelsa H. and B. ("castanheira") nas regiões de Carajás e Marabá, estado do Pará. Boletim do Museo Paranaense Emílio Goeldi, Serie Botanica 7:47-68.

Schöngart, J., R. Gribel, S. Ferreira da Fonseca-Junior, and T. Haugaasen. 2015. Age and growth patterns of Brazil nut trees (Bertholletia excelsa Bonpl.) in Amazonia, Brazil. Biotropica 47:550-558. http://dx.doi.org/10.1111/btp.12243

Schulze, M., J. Grogan, R. Matthew Landis, and E. Vidal. 2008. How rare is too rare to harvest?: management challenges posed by timber species occurring at low densities in the Brazilian Amazon. Forest Ecology and Management 256:1443-1457. http:// dx.doi.org/10.1016/j.foreco.2008.02.051

Scoles, R., and R. Gribel. 2011. Population structure of Brazil nut (Bertholletia excelsa, Lecythidaceae) stands in two areas with different occupation histories in the Brazilian Amazon. Human Ecology 39:455-464. http://dx.doi.org/10.1007/s10745-011-9412-0

Shanley, P., and G. Medina. 2005. Frutíferas e plantas úteis na vida Amazonica. Center for International Forestry Research and Imazon, Belém, Brazil. [online] URL: http://webcache. googleusercontent.com/search?q=cache:JchAH7JGHjcJ:www.cifor. org/library/1732/frutiferas-e-plantas-uteis-na-vida-amazonica-2/+ $\underline{\& c d}=2 \& h l=e n \& c t=\operatorname{lnk} \& g l=c a$

Shepard, Jr., G. H., and H. Ramirez. 2011. "Made in Brazil": human dispersal of Brazil nuts (Bertholletia excelsa, Lecythidaceae) in Ancient Amazonia. Economic Botany 65:44-65. http://dx.doi.org/10.1007/s12231-011-9151-6

Sills, E. O., S. S. Atmadja, C. de Sassi, A. E. Duchelle, D. L. Kweka, I. A. P. Resosudarmo, and W. D. Sunderlin. 2014. REDD+on the ground: a case book of subnational initiatives across the globe. Center for International Forestry Research, Bogor, Indonesia. [online] URL: http://www.cifor.org/library/5202/redd-on-theground-a-case-book-of-subnational-initiatives-across-the-globe/

Soliz, L. 2009. Tierras fiscales y asentamientos humanos en la amazonía boliviana, más allá de la politización. Documento de trabajo. Centro de Investigacion y Promocion del Campesinado, La Paz, Bolivia. [online] URL: http://www.cipca.org.bo/index. php/cipca-notas/zdpa/476--sp-1007732040

Southworth, J., M. Marsik, Y. Qiu, S. Perz, G. Cumming, F. Stevens, K. Rocha, A. Duchelle, and G. Barnes. 2011. Roads as drivers of change: trajectories across the tri-national frontier in MAP, the Southwestern Amazon. Remote Sensing 3:1047-1066. http://dx.doi.org/10.3390/rs3051047

The Economics of Ecosystems and Biodiversity (TEEB). 2013. TEEBcase: implication of Chico Mendes Law in Acre, Brazil. Compiled by Carolin Kugel and Sanjib Kumar Jha, mainly based on Veríssimo et al. 2002 "Payment for environmental services". TEEB, Geneva, Switzerland. [online] URL: http://img.teebweb. org/wp-content/uploads/2013/12/Subsidy-for-traditional-rubberproduction_-Brazil_pdf

Thomas, E., C. Alcázar Caicedo, C. H. McMichael, R. Corvera, and J. Loo. 2015. Uncovering spatial patterns in the natural and human history of Brazil nut (Bertholletia excelsa) across the Amazon Basin. Journal of Biogeography 42:1367-1382. http://dx. doi.org/10.1111/jbi. 12540

Thomas, E., and I. Vandebroek. 2006. Guía de plantas medicinales de los Yuracarés y Trinitarios del Territorio Indígena Nacional Isiboro-Sécure, Bolivia. Imprenta Sirena, Santa Cruz, Bolivia.

United Nations. 2015. Paris agreement. Art. 5. United Nations, Bonn, Germany. [online] URL: http://unfccc.int/paris_agreement/ items/9485.php

van Andel, T. R. 2000. Non-timber forest products of the NorthWest District of Guyana, Part II, a field guide. Tropenbos-Guyana Series 8b. Tropenbos-Guyana Programme, Georgetown, Guyana.

van Gardingen, P. R., D. Valle, and I. Thompson. 2006. Evaluation of yield regulation options for primary forest in Tapajos National Forest, Brazil. Forest Ecology and Management 231:184-195. http://dx.doi.org/10.1016/j.foreco.2006.05.047

Vargas, I., B. Mostacedo, and C. Jordán. 2005. Guía ilustrada de las principales especies forestales de Bolivia. Instituto Boliviano de Investigación Forestal, Santa Cruz, Bolivia.

Vieira, R. F., T. da Silva Agostini Costa, D. Barbosa da Silva, R. F. Ferreira, and S. Matiko Sano. 2006. Frutas nativas da região Centro-Oeste do Brasil. Empresa Brasileira de Pesquisa Agropecuária Ministério da Agricultura, Pecuária e Abastecimento (EMBRAPA), Brasília, Brazil. [online] URL: http://www. agabrasil.org.br/_Dinamicos/livro_frutas_nativas_Embrapa.pdf

Villachica, H., J. E. U. de Carvalho, C. H. Muller, C. Diaz S., and M. Almanza. 1996. Frutales y hortalizas promisorias de la Amazonía. Tratado de Cooperación Amazónica, Lima, Peru.

Wadt, L. H. O., K. A. Kainer, C. L. Staudhammer, and R. O. P. Serrano. 2008. Sustainable forest use in Brazilian extractive reserves: natural regeneration of Brazil nut in exploited populations. Biological Conservation 141:332-346. http://dx.doi. org/10.1016/j.biocon.2007.10.007

Wadt, L. H. O., K. A. Kainer, and D. A. P. Gomes-Silva. 2005. Population structure and nut yield of a Bertholletia excelsa stand in Southwestern Amazonia. Forest Ecology and Management 211:371-384. http://dx.doi.org/10.1016/j.foreco.2005.02.061

Watson, R. T., I. R. Noble, B. Bolin, N. H. Ravindranath, D. J. Verardo, and D. J. Dokken. 2000. Land use, land-use change and forestry. Intergovernmental Panel on Climate Change (IPCC). Cambridge University Press, Cambridge, UK.

West, T. A. P., E. Vidal, and F. E. Putz. 2014f. Forest biomass recovery after conventional and reduced-impact logging in Amazonian Brazil forest ecology and management. Forest Ecology and Management 314:59-63. http://dx.doi.org/10.1016/j. foreco.2013.11.022 
Zanne, A. E., G. Lopez-Gonzalez, D. A. Coomes, J. Ilic, S. Jansen, S. L. Lewis, R. B. Miller, N. G. Swenson, M. C. Wiemann, and J. Chave. 2009. Global wood density database. Dryad. [online] URL: http://hdl.handle.net/10255/dryad.235

Zuidema, P. A. 2003. Ecology and management of the Brazil nut tree (Bertholletia excelsa). Programa de Manejo de Bosques de la Amazonia Boliviana (PROMAB). Scientific series 6. PROMAB, Riberalta, Bolivia.

Zuidema, P. A., and R. G. A. Boot. 2002. Demography of the Brazil nut tree (Bertholletia excelsa) in the Bolivian Amazon: impact of seed extraction on recruitment and population dynamics. Journal of Tropical Ecology 18:1-31. http://dx.doi. org/10.1017/S0266467402002018 
Appendix 1. Description of 19 sites sampled in 41-1 ha forest plots located in Madre de Dios (Peru), Acre (Brazil) and Pando (Bolivia) in southwestern Amazonia

\begin{tabular}{|c|c|c|c|c|c|c|c|c|}
\hline Region & $\begin{array}{l}\text { Plot } \\
\text { name }\end{array}$ & $X$ & Y & Altitude & $\begin{array}{l}\text { Forest } \\
\text { type }\end{array}$ & $\begin{array}{l}\text { Forest } \\
\text { composition }\end{array}$ & Edaphic type & Reference \\
\hline $\begin{array}{l}\text { Madre de } \\
\text { Dios }\end{array}$ & TAM-01 & 468700 & 8580079 & 215 & Alluvial & $\begin{array}{l}\text { mixed } \\
\text { forest }\end{array}$ & Former floodplain & https://www.forestplots.net/ \\
\hline $\begin{array}{l}\text { Madre de } \\
\text { Dios }\end{array}$ & TAM-02 & 468947 & 8581150 & 214 & Alluvial & $\begin{array}{l}\text { mixed } \\
\text { forest }\end{array}$ & Former floodplain & https://www.forestplots.net \\
\hline $\begin{array}{l}\text { Madre de } \\
\text { Dios }\end{array}$ & TAM-05 & 470636 & 8581609 & 216 & Forest dense & $\begin{array}{l}\text { mixed } \\
\text { forest }\end{array}$ & Terra firme & https://www.forestplots.net/ \\
\hline $\begin{array}{l}\text { Madre de } \\
\text { Dios } \\
\text { Madre de }\end{array}$ & TAM-06 & 467884 & 8580695 & 205 & $\begin{array}{l}\text { Forest dense } \\
\text { alluvial }\end{array}$ & $\begin{array}{l}\text { mixed } \\
\text { forest } \\
\text { mixed }\end{array}$ & Terra firme & https://www.forestplots.net \\
\hline $\begin{array}{l}\text { Dios } \\
\text { Madre de }\end{array}$ & TAM-07 & 471655 & 8582109 & 228 & Forest dense & $\begin{array}{l}\text { forest } \\
\text { mixed }\end{array}$ & Terra firme & https://www.forestplots.net \\
\hline Dios & TAM-08 & 470766 & 8582047 & 225 & Forest dense & forest & Terra firme & https://www.forestplots.net \\
\hline $\begin{array}{l}\text { Madre de } \\
\text { Dios }\end{array}$ & TAM-09 & 469152 & 8581543 & 212 & $\begin{array}{l}\text { Forest dense } \\
\text { alluvial }\end{array}$ & $\begin{array}{l}\text { mixed } \\
\text { forest }\end{array}$ & Former floodplain & https://www.forestplots.net \\
\hline $\begin{array}{l}\text { Madre de } \\
\text { Dios }\end{array}$ & CUZ-01 & 493489 & 8613972 & 205 & $\begin{array}{l}\text { Forest dense } \\
\text { alluvial }\end{array}$ & $\begin{array}{l}\text { mixed } \\
\text { forest }\end{array}$ & Former floodplain & https://www.forestplots.net \\
\hline $\begin{array}{l}\text { Madre de } \\
\text { Dios }\end{array}$ & CUZ-02 & 493718 & 8613742 & 209 & $\begin{array}{l}\text { Forest dense } \\
\text { alluvial }\end{array}$ & $\begin{array}{l}\text { mixed } \\
\text { forest }\end{array}$ & Former floodplain & https://www.forestplots.net \\
\hline $\begin{array}{l}\text { Madre de } \\
\text { Dios }\end{array}$ & CUZ-03 & 494138 & 8614363 & 206 & $\begin{array}{l}\text { Forest dense } \\
\text { alluvial }\end{array}$ & $\begin{array}{l}\text { mixed } \\
\text { forest }\end{array}$ & Former floodplain & https://www.forestplots.net \\
\hline $\begin{array}{l}\text { Madre de } \\
\text { Dios }\end{array}$ & CUZ-04 & 494405 & 8614135 & 203 & $\begin{array}{l}\text { Forest dense } \\
\text { alluvial }\end{array}$ & $\begin{array}{l}\text { mixed } \\
\text { forest }\end{array}$ & Former floodplain & https://www.forestplots.net \\
\hline $\begin{array}{l}\text { Madre de } \\
\text { Dios }\end{array}$ & $\begin{array}{l}\text { ALM- } \\
\text { OA1 }\end{array}$ & 231208 & 8694378 & 396 & Forest dense & $\begin{array}{l}\text { mixed } \\
\text { forest }\end{array}$ & Former floodplain & https://www.forestplots.net \\
\hline $\begin{array}{l}\text { Madre de } \\
\text { Dios }\end{array}$ & $\begin{array}{l}\text { ALM- } \\
\text { OA2 }\end{array}$ & 231208 & 8694378 & 396 & Forest dense & $\begin{array}{l}\text { mixed } \\
\text { forest }\end{array}$ & Former floodplain & https://www.forestplots.net/ \\
\hline $\begin{array}{l}\text { Madre de } \\
\text { Dios }\end{array}$ & LAS-02 & 379762 & 8611685 & 200 & Forest dense & $\begin{array}{l}\text { mixed } \\
\text { forest }\end{array}$ & Former floodplain & https://www.forestplots.net/ \\
\hline $\begin{array}{l}\text { Madre de } \\
\text { Dios }\end{array}$ & $\begin{array}{l}\text { LAS- } \\
\text { OA1 }\end{array}$ & 379762 & 8611685 & 200 & Forest dense & $\begin{array}{l}\text { mixed } \\
\text { forest }\end{array}$ & Terra firme & https://www.forestplots.net \\
\hline $\begin{array}{l}\text { Madre de } \\
\text { Dios }\end{array}$ & $\begin{array}{l}\text { LAS- } \\
\text { OA2 }\end{array}$ & 379762 & 8611685 & 200 & Forest dense & $\begin{array}{l}\text { mixed } \\
\text { forest }\end{array}$ & Terra firme & https://www.forestplots.net \\
\hline Acre & POR-01 & 525027 & 8803698 & 276 & $\begin{array}{l}\text { Forest open } \\
\text { palm+dense }\end{array}$ & $\begin{array}{l}\text { mixed } \\
\text { forest }\end{array}$ & Terra firme & https://www.forestplots.net \\
\hline Acre & POR-02 & 525200 & 8806372 & 270 & $\begin{array}{l}\text { Forest open } \\
\text { palm+dense }\end{array}$ & $\begin{array}{l}\text { mixed } \\
\text { forest }\end{array}$ & Terra firme & https://www.forestplots.net \\
\hline Acre & DOI-01 & 574810 & 8831928 & 198 & $\begin{array}{l}\text { Forest open } \\
\text { palm alluvial }\end{array}$ & $\begin{array}{l}\text { mixed } \\
\text { forest }\end{array}$ & Terra firme & https://www.forestplots.net \\
\hline
\end{tabular}

Continuation Appendix 1. 


\begin{tabular}{|c|c|c|c|c|c|c|c|c|}
\hline Region & $\begin{array}{l}\text { Plot } \\
\text { name }\end{array}$ & $x$ & Y & Altitude & Forest type & Forest composition & $\begin{array}{l}\text { Edaphic } \\
\text { type }\end{array}$ & Reference \\
\hline Acre & DOI-02 & 575864 & 8833916 & 205 & $\begin{array}{l}\text { Forest open } \\
\text { bamboo+palm } \\
\text { +dense }\end{array}$ & bamboo dominated & Terra firme & https://www.forestplots. \\
\hline Acre & RFH-01 & 645677 & 8921884 & 173 & $\begin{array}{l}\text { Forest open } \\
\text { bamboo+palm }\end{array}$ & mixed forest & Terra firme & $\begin{array}{l}\text { https://www.forestplots. } \\
\text { net/ }\end{array}$ \\
\hline Acre & RST-01 & 140796 & 8999012 & 271 & $\begin{array}{l}\text { palm+bamboo } \\
\text { +dense }\end{array}$ & mixed forest & Terra firme & $\frac{\text { https://www.forestplots. }}{\underline{\text { net }}}$ \\
\hline Acre & МTH-01 & 82805 & 9015922 & 239 & $\begin{array}{l}\text { Forest open } \\
\text { palm+bamboo }\end{array}$ & mixed forest & Terra firme & $\frac{\text { https://www.forestplots. }}{\underline{\text { net }}}$ \\
\hline Acre & MIN-01 & 70250 & 9050569 & 230 & $\begin{array}{l}\text { Forest open } \\
\text { palm }\end{array}$ & mixed forest & Terra firme & https://www.forestplots. \\
\hline Pando & EBT-03 & 497780 & 8738956 & 258 & Forest dense & mixed forest & Terra firme & $\underline{\text { Unpublished }}$ \\
\hline Pando & EBT-04 & 498267 & 8739349 & 281 & Forest dense & mixed forest & Terra firme & Unpublished \\
\hline Pando & SSI-01 & 520544 & 8761323 & 268 & Forest dense & mixed forest & Terra firme & Unpublished \\
\hline Pando & CIB-01 & 521475 & 8761560 & 268 & Forest dense & mixed forest & Terra firme & Unpublished \\
\hline Pando & LPD-06 & 810785 & 8778225 & 145 & Forest dense & mixed forest & Terra firme & Unpublished \\
\hline Pando & SLC-05 & 621291 & 8778637 & 243 & Forest dense & mixed forest & Terra firme & $\frac{\text { Unpublished }}{\text { https://www.forestplots. }}$ \\
\hline Pando & RET-05 & 859054 & 8785263 & 145 & Forest dense & mixed forest & Terra firme & $\frac{\overline{\text { net/ }}}{\text { https://www.forestplots. }}$ \\
\hline Pando & RET-06 & 859054 & 8785263 & 145 & Forest dense & mixed forest & Terra firme & $\frac{\text { net/ }}{\text { https://www.forestplots. }}$ \\
\hline Pando & RET -08 & 859054 & 8785263 & 145 & Forest dense & mixed forest & Terra firme & $\frac{\overline{\text { net/ }}}{\text { https://www.forestplots. }}$ \\
\hline Pando & RET-09 & 859054 & 8785263 & 145 & Forest dense & mixed forest & Terra firme & $\frac{\overline{\text { net/ }}}{\text { https://www.forestplots. }}$ \\
\hline Pando & MBT -01 & 841012 & 8887308 & 154 & Forest dense & mixed forest & Terra firme & net \\
\hline Pando & MBT-02 & 877414 & 8858679 & 145 & Forest dense & mixed forest & Terra firme & $\begin{array}{l}\text { https://www.forestplots. } \\
\text { net }\end{array}$ \\
\hline Pando & MBT -04 & 869672 & 8888990 & 148 & $\begin{array}{l}\text { Forest open } \\
\text { palm }\end{array}$ & mixed forest & Terra firme & https://www.forestplots. \\
\hline Pando & MBT -05 & 868261 & 8888607 & 147 & $\begin{array}{l}\text { Forest open } \\
\text { palm }\end{array}$ & mixed forest & Terra firme & https://www.forestplots. \\
\hline Pando & MBT -06 & 868261 & 8888607 & 147 & $\begin{array}{l}\text { Forest open } \\
\text { palm }\end{array}$ & mixed forest & Terra firme & https://www.forestplots. \\
\hline Pando & MBT -07 & 856328 & 8899394 & 140 & $\begin{array}{l}\text { Forest dense } \\
\text { alluvial+palm+ } \\
\text { bamboo } \\
\text { Forest dense } \\
\text { alluvial+palm+ } \\
\text { bamboo }\end{array}$ & mixed forest & $\begin{array}{l}\text { Former } \\
\text { floodplain } \\
\text { Former } \\
\text { floodplain }\end{array}$ & $\begin{array}{l}\frac{\text { https://www.forestplots. }}{\text { net/ }} \\
\text { https://www.forestplots. } \\
\text { net/ }\end{array}$ \\
\hline
\end{tabular}


Appendix 2. Mean density (stems per hectare) of taxa sampled in 41 ha plots in forest of southwestern Amazonia

\begin{tabular}{|c|c|c|c|c|c|}
\hline Non-timber species & $\begin{array}{l}\text { stems per } \\
\text { hectare }\end{array}$ & Timber & $\begin{array}{l}\text { Stems } \\
\text { per } \\
\text { hectare }\end{array}$ & Timber species & $\begin{array}{l}\text { Stems per } \\
\text { hectare }\end{array}$ \\
\hline Iriartea deltoidea & 23.88 & Clarisia racemosa & 2.98 & Brosimum rubescens & 0.54 \\
\hline Euterpe precatoria & 16.29 & Virola spp. & 2.78 & Matisia cordata & 0.54 \\
\hline Siparuna decipiens & 10.49 & Pseudolmedia macrophylla & 2.41 & Virola surinamensis & 0.54 \\
\hline Socratea exorrhiza & 7.00 & Pseudolmedia spp. & 2.22 & Aniba canelilla & 0.51 \\
\hline Attalea butyracea & 5.66 & Virola calophylla & 2.10 & Hymenaea parvifolia & 0.51 \\
\hline Oenocarpus bataua & 4.12 & Brosimum spp. & 2.05 & Inga edulis & 0.51 \\
\hline Theobroma cacao & 3.05 & Inga capitata & 1.93 & $\begin{array}{l}\text { Cedrelinga } \\
\text { cateniformis }\end{array}$ & 0.49 \\
\hline Pouteria torta & 2.46 & Virola sebifera & 1.83 & Myroxylon balsamum & 0.49 \\
\hline Bertholletia excelsa & 1.54 & Matisia spp. & 1.76 & Inga marginata & 0.46 \\
\hline Attalea phalerata & 1.17 & Jacaranda copaia & 1.51 & Tapura juruana & 0.46 \\
\hline Hevea brasiliensis & 0.98 & Protium amazonicum & 1.51 & Virola elongata & 0.44 \\
\hline Poulsenia armata & 0.90 & Peltogyne heterophylla & 1.39 & Inga auristellae & 0.41 \\
\hline Oenocarpusmapora & 0.85 & Ocotea spp. & 1.37 & Ficus spp. & 0.41 \\
\hline Endopleura uchi & 0.80 & Chrysophyllum venezuelanense & 1.34 & Inga laurina & 0.39 \\
\hline Astrocaryum gratum & 0.59 & Dialium guianense & 1.29 & Spondias mombin & 0.39 \\
\hline Astrocaryum spp. & 0.51 & Castilla ulei & 1.27 & Anacardium giganteum & 0.37 \\
\hline Attalea spp. & 0.41 & Unonopsis matthewsii & 1.02 & Aniba taubertiana & 0.37 \\
\hline Pouteria caimito & 0.29 & Tachigali paniculata & 1.00 & $\begin{array}{l}\text { Calophyllum } \\
\text { brasiliense }\end{array}$ & 0.34 \\
\hline Mauritia flexuosa & 0.12 & Brosimum alicastrum & 0.98 & $\begin{array}{l}\text { Enterolobium } \\
\text { schomburgkii }\end{array}$ & 0.34 \\
\hline Attalea maripa & 0.07 & Minquartia guianensis & 0.93 & $\begin{array}{l}\text { Protium } \\
\text { rhynchophyllum }\end{array}$ & 0.34 \\
\hline Bactris gasipaes & 0.02 & Aniba spp. & 0.88 & Protium sagotianum & 0.34 \\
\hline Chelyocarpus chuco & 0.02 & Astronium lecontei & 0.85 & Tabebuia incana & 0.32 \\
\hline Timber & & Aspidosperma vargasii & 0.83 & Cabralea canjerana & 0.29 \\
\hline Pseudolmedia laevis & 21.27 & Aspidosperma spp. & 0.71 & Cedrela odorata & 0.29 \\
\hline Tetragastris altissima & 13.37 & Hevea spp. & 0.71 & Cordia alliodora & 0.29 \\
\hline Iryanthera juruensis & 7.61 & Matisia ochrocalyx & 0.68 & $\begin{array}{l}\text { Huberodendron } \\
\text { swietenioides }\end{array}$ & 0.29 \\
\hline Tetragastris panamensis & 6.51 & Apuleia leiocarpa & 0.66 & Inga alba & 0.29 \\
\hline Pseudolmedia laevigata & 6.49 & Pseudolmedia murure & 0.66 & Inga chartacea & 0.29 \\
\hline Inga spp. & 5.78 & Virola flexuosa & 0.66 & Inga punctata & 0.29 \\
\hline Brosimum lactescens & 5.51 & Iryanthera spp. & 0.66 & Protium aracouchini & 0.29 \\
\hline Celtis schippii & 4.17 & Ocotea bofo & 0.61 & Terminalia oblonga & 0.29 \\
\hline Protium spp. & 3.83 & Unonopsis spp. & 0.61 & Protium nodulosum & 0.27 \\
\hline Eschweilera coriacea & 3.54 & Couratari macrosperma & 0.56 & Couratari spp. & 0.27 \\
\hline Brosimum guianense & 3.12 & Chrysophyllum spp. & 0.56 & Aniba terminalis & 0.24 \\
\hline
\end{tabular}


continue appendix 2

\begin{tabular}{|c|c|c|c|c|c|}
\hline Timber species & $\begin{array}{l}\text { Stems per } \\
\text { hectare }\end{array}$ & Timber species & $\begin{array}{l}\text { Stems } \\
\text { per } \\
\text { hectare }\end{array}$ & Timber species & $\begin{array}{l}\text { Stems per } \\
\text { hectare }\end{array}$ \\
\hline Gallesia integrifolia & 0.24 & Mezilaurus itauba & 0.15 & Cariniana estrellensis & 0.07 \\
\hline Guarea guidonia & 0.24 & Ocotea rubrinervis & 0.15 & Ceiba speciosa & 0.07 \\
\hline Hura crepitans & 0.24 & Virola multinervia & 0.15 & Chorisia insignis & 0.07 \\
\hline Inga coruscans & 0.24 & Ceiba spp. & 0.15 & Dipteryx ferrea & 0.07 \\
\hline Inga sarmentosa & 0.24 & Clarisia spp. & 0.15 & Dipteryx micrantha & 0.07 \\
\hline Manilkara bidentata & 0.24 & Terminalia spp. & 0.15 & Ficus trigona & 0.07 \\
\hline Protium puncticulatum & 0.24 & Vochysia spp. & 0.15 & Inga coriacea & 0.07 \\
\hline Schefflera morototoni & 0.24 & Amburana cearensis & 0.12 & Inga pavoniana & 0.07 \\
\hline Astronium spp. & 0.24 & Andira surinamensis & 0.12 & Inga quaternata & 0.07 \\
\hline Tabebuia spp. & 0.24 & Brosimum parinarioides & 0.12 & Inga stipularis & 0.07 \\
\hline Terminalia amazonia & 0.24 & Copaifera reticulata & 0.12 & Inga striata & 0.07 \\
\hline $\begin{array}{l}\text { Aniba panurensis } \\
\text { Aspidosperma }\end{array}$ & 0.22 & Couma macrocarpa & 0.12 & Inga suaveolens & 0.07 \\
\hline macrocarpon & 0.22 & Dipteryx odorata & 0.12 & Matisia rhombifolia & 0.07 \\
\hline Cariniana micrantha & 0.22 & Ficus gomelleira & 0.12 & Ocotea cernua & 0.07 \\
\hline Ceiba pentandra & 0.22 & Inga leiocalycina & 0.12 & Ocotea oblonga & 0.07 \\
\hline Ficus maxima & 0.22 & Inga splendens & 0.12 & Ocotea puberula & 0.07 \\
\hline Parkia pendula & 0.22 & Virola mollissima & 0.12 & Protium carnosum & 0.07 \\
\hline Protium calendulinum & 0.22 & Calycophyllum spp. & 0.12 & Protium neglectum & 0.07 \\
\hline Aniba guianensis & 0.20 & Cariniana spp. & 0.12 & Protium paniculatum & 0.07 \\
\hline Inga acreana & 0.20 & Chorisia spp. & 0.12 & Protium robustum & 0.07 \\
\hline Protium crassipetalum & 0.20 & Mezilaurus spp. & 0.12 & Virola loretensis & 0.07 \\
\hline Chimarrhis spp. & 0.20 & Andira inermis & 0.10 & Enterolobium spp. & 0.07 \\
\hline Tetragastris spp. & 0.20 & Astronium graveolens & 0.10 & Ceiba insignis & 0.05 \\
\hline Hymenaea oblongifolia & 0.17 & Ceiba samauma & 0.10 & Chimarrhis hookeri & 0.05 \\
\hline Inga acrocephala & 0.17 & Chimarrhis glabriflora & 0.10 & Chorisia integrifolia & 0.05 \\
\hline Inga bourgonii & 0.17 & Inga sertulifera & 0.10 & Chorisia speciosa & 0.05 \\
\hline Inga ruiziana & 0.17 & Protium opacum & 0.10 & Couroupita guianensis & 0.05 \\
\hline Matisia bicolor & 0.17 & Virola decorticans & 0.10 & Dipteryx alata & 0.05 \\
\hline Pseudolmedia rigida & 0.17 & Virola michelii & 0.10 & Ficus citrifolia & 0.05 \\
\hline Aniba muca & 0.15 & Virola pavonis & 0.10 & Ficus guianensis & 0.05 \\
\hline Couratari guianensis & 0.15 & Virola peruviana & 0.10 & Ficus insipida & 0.05 \\
\hline Hymenaea courbaril & 0.15 & Cedrela spp. & 0.10 & Ficus killipii & 0.05 \\
\hline Inga nobilis & 0.15 & Hymenaea spp. & 0.10 & Guazuma crinita & 0.05 \\
\hline Inga tenuistipula & 0.15 & Aniba puchury-minor & 0.07 & Inga fendleriana & 0.05 \\
\hline
\end{tabular}


continue Appendix 2.

\begin{tabular}{|c|c|c|c|c|c|}
\hline Timber species & $\begin{array}{l}\text { Stems per } \\
\text { hectare }\end{array}$ & Timber species & $\begin{array}{l}\text { Stems } \\
\text { per } \\
\text { hectare }\end{array}$ & Timber species & $\begin{array}{l}\text { Stems per } \\
\text { hectare }\end{array}$ \\
\hline Protium neglectum & 0.07 & Cedrela fissilis & 0.02 & $\begin{array}{l}\text { Schizolobium } \\
\text { amazonicum }\end{array}$ & 0.02 \\
\hline Protium paniculatum & 0.07 & Enterolobium barnebianum & 0.02 & Sweetia fruticosa & 0.02 \\
\hline Protium robustum & 0.07 & Ficus caballina & 0.02 & Virola multiflora & 0.02 \\
\hline Virola loretensis & 0.07 & Ficus coerulescens & 0.02 & Vitex cymosa & 0.02 \\
\hline Enterolobium spp. & 0.07 & Ficus cuatrecasasiana & 0.02 & Vochysia obidensis & 0.02 \\
\hline Ceiba insignis & 0.05 & Ficus donnell-smithii & 0.02 & Vochysia stafleui & 0.02 \\
\hline Chimarrhis hookeri & 0.05 & Ficus eximia & 0.02 & Pradosia spp. & 0.02 \\
\hline Chorisia integrifolia & 0.05 & Ficus krukovii & 0.02 & Protium glabrescens & 0.02 \\
\hline Chorisia speciosa & 0.05 & Ficus schultesii & 0.02 & Symphonia spp. & 0.02 \\
\hline Couroupita guianensis & 0.05 & Ficus sphenophylla & 0.02 & & \\
\hline Dipteryx alata & 0.05 & Ficus ypsilophlebia & 0.02 & & \\
\hline Ficus citrifolia & 0.05 & Hymenaea reticulata & 0.02 & & \\
\hline Ficus guianensis & 0.05 & Inga acuminata & 0.02 & & \\
\hline Ficus insipida & 0.05 & Inga aggregata & 0.02 & & \\
\hline Ficus killipii & 0.05 & Inga bracteosa & 0.02 & & \\
\hline Guazuma crinita & 0.05 & Inga cinnamomea & 0.02 & & \\
\hline Inga fendleriana & 0.05 & Inga grandis & 0.02 & & \\
\hline Inga heterophylla & 0.05 & Inga lateriflora & 0.02 & & \\
\hline Inga microcoma & 0.05 & Inga macrophylla & 0.02 & & \\
\hline Inga spectabilis & 0.05 & Inga peltadenia & 0.02 & & \\
\hline Inga thibaudiana & 0.05 & Inga pezizifera & 0.02 & & \\
\hline Inga tomentosa & 0.05 & Inga semialata & 0.02 & & \\
\hline Mezilaurus subcordata & 0.05 & Inga stipulacea & 0.02 & & \\
\hline Ocotea camphoromoea & 0.05 & Inga velutina & 0.02 & & \\
\hline Ocotea tessmannii & 0.05 & Inga venusta & 0.02 & & \\
\hline Pourouma bicolor & 0.05 & Ocotea javitensis & 0.02 & & \\
\hline Virola parvifolia & 0.05 & Ocotea longifolia & 0.02 & & \\
\hline Vochysia inundata & 0.05 & Peltogyne confertiflora & 0.02 & & \\
\hline Amburana spp. & 0.05 & Peltogyne floribunda & 0.02 & & \\
\hline Dipteryx spp. & 0.05 & Protium insigne & 0.02 & & \\
\hline Peltogyne spp. & 0.05 & Protium meridionale & 0.02 & & \\
\hline Andira multistipula & 0.02 & Protium pallidum & 0.02 & & \\
\hline Aniba megaphylla & 0.02 & Protium spruceanum & 0.02 & & \\
\hline $\begin{array}{l}\text { Calycophyllum } \\
\text { spruceanum }\end{array}$ & 0.02 & Protium tenuifolium & 0.02 & & \\
\hline
\end{tabular}

